\title{
Subsurface temperature of the onshore Netherlands: new temperature dataset and modelling
}

\section{Bonté ${ }^{1,3,{ }^{*},}$ J.-D. van Wees ${ }^{1,2}$ \& J.M. Verweij ${ }^{2}$}

1 Utrecht University, Budapestlaan 4, 3584 CD Utrecht, the Netherlands.

2 TNO - Geological Survey of the Netherlands, Princetonlaan 6, 3584 CB Utrecht, the Netherlands.

3 Present address: GeoServ, Unit1, Ballyogan Road, Dublin 18, Ireland.

* Corresponding author. Email: dam.bonte@gmail.com.

Manuscript received: December 2011, accepted: July 2012

\begin{abstract}
Subsurface temperature is a key parameter for geothermal energy prospection in sedimentary basins. Here, we present the results of a 3D temperature modelling using a thermal-tectonic forward modelling method, calibrated with subsurface temperature measurements in the Netherlands. The first step involves the generation of a coherent dataset of temperature values for the calibration of the model. In the Netherlands, most of the available measurements (98.8\%) are BHT measurements and therefore need to be corrected from the thermal perturbation created during drilling. The remaining $1.2 \%$ is composed of DST measurements, which closely resemble the formation temperature (i.e., $\pm 5^{\circ} \mathrm{C}$ ). The resulting dataset, after correction, gives a total number of 1293 values in 454 wells. Included in this dataset are 412 highly reliable values corrected with the Instantaneous Cylinder Source (ICS) method and 829 values of a lower reliability corrected with the AAPG method. In addition to the corrected values, 52 DST values in 26 wells are available from the Dutch subsurface. The average thermal gradient of this whole dataset is $31.3^{\circ} \mathrm{C} / \mathrm{km}$ with a surface temperature of $10.1^{\circ} \mathrm{C}$. The second step in the modelling process was the generation of a $3 \mathrm{D}$ forward model that focuses on calculating the temperature distribution of the sedimentary basin fill, taking into account the basin evolution of the past 20 Myrs and thermal properties and processes of the whole lithosphere. From the 3D thermal model, we extracted 2D cross sections across well locations to compare model temperatures with calibration data. Furthermore, we present vertical profiles, isodepth maps and temperature projection on geological layers, to discuss the relationship between temperature and geology. Anomalies in this relationship can have several causes and include: 1) the extreme thermal conductivity and complex geometry of the Zechstein salt; 2) enhanced radiogenic heat production of the upper crust due to magmatic intrusions. In addition, our model supports earlier findings that shallow hydrothermal convection in highly permeable sediments can effectively lower thermal conductivity and temperatures in shallow sediments.
\end{abstract}

Keywords: basin modelling, BHT, geothermal energy, temperature, the Netherlands

\section{Introduction}

As awareness of the impact of human activity on the environment continues to rise, there is an increased focus on the role that renewable energy sources might play in providing clean energy. Geothermal energy is one of the better alternatives to traditional energy sources, as it is a renewable, nearly infinite energy source and is independent of fluctuating seasonal or climatic conditions. According to the IGA (International Geothermal Agency), the classification of geothermal resources has evolved in recent decades. Before 1990, geothermal resources were classified as low, intermediate, and high enthalpy (Muffler \& Cataldi, 1978; Hochstein, 1990; Benderitter \& Cormy, 1990). Since 1990 however, only the extreme categories of low and high enthalpy have been maintained (Nicholson, 1993; Axelsson \& Gunnlaugsson, 2000). These two categories can be related to the two main uses of geothermal energy: the direct use of heat and the generation of electricity. While the use of fluid over $150-190^{\circ} \mathrm{C}$ is usually dedicated to electricity generation, below these temperatures the use of geothermal energy is very 
varied, ranging from spa treatments to the heating of greenhouses or entire districts (Lindal, 1973). Each of these domains is marked by its own specific requirements and temperature demands. For example, in Iceland temperatures are decreased so that they can be used for the growing of tomatoes in greenhouses. In the Netherlands, geothermal energy has seen a very rapid growth in the last five years, increasing from a single exploitation permit in 2007 to the granting of some ninety permits for exploration and exploration in 2011 (www.nlog.nl). This trend is set to continue in coming years, with tens of requests submitted to the Ministry of Economic Affairs (Kramers et al., this issue). At present, the growth of geothermal energy in the Netherlands is mainly low-enthalpy heating of districts and greenhouses. Geothermal exploration is widespread throughout much of the Netherlands (Kramers et al., this issue). The targeted layers for geothermal exploration are sandstones from the Cretaceous (Rijnland Group) and Jurassic (Schieland Group) in the south of the country and Permian (Slochteren Formation) in the north. The main location of interest, however, is the West Netherlands Basin to the southwest of the country. Here, energy and demand are found in the same location, with the excellent potential of sandstones in the Rijnland Group providing heating for an existing area of greenhouses (Pluymaekers et al., this issue).

The primary aim of this study is to provide an up-to-date temperature dataset that is larger and more precise than the latest published Ramaekers (1992) dataset. This temperature dataset, which is close to the formation temperature, uses the existing datasets obtained from drill holes that are available at TNO and which are corrected for perturbations related to drilling. The second objective is to perform a $3 \mathrm{D}$ thermal modelling using a tectonic heat flow method that is based on the thermal properties of the sedimentary structure. Transient effects will be taken into consideration through the variation of surface temperature and vertical motions (erosion and sedimentation). The result is a $3 \mathrm{D}$ thermal block that we can present both through the usual isodepth map (i.e., a temperature map at a fixed depth) and also on profiles and geological layers.

\section{Previous works on the temperature in the Netherlands}

Research on subsurface temperature in the Netherlands has been carried out for over a century. The first reference to a temperature measurement is from Harting (1879), and was carried out in a $369 \mathrm{~m}$ depth well drilled in the city of Utrecht in 1872. Temperature measurements can have a number of purposes, with clear examples being the calculation of volumetric gas in place in the Groningen area (Van Engen, 1975) or the assessment of working conditions in the mines in SouthLimburg (Sadee, 1975). Temperature maps and datasets of the Dutch subsurface comply with each new edition of the European geothermal atlas (see Table 3 for the atlases). The temperature compilation of Prins (1980) featured in the Atlas of subsurface temperatures in the European Community of Haenel et al. (1980) is the first evidence of a deep subsurface generated dataset on a countrywide scale. Unfortunately, details about the dataset used to generate the maps available in the atlas of Haenel et al. (1980) are not mentioned. However, the number of thermal isodepth maps featured in this atlas is the highest yet published. Alongside a Dutch map giving the temperature at $1000 \mathrm{~m}$, six isodepth maps showing temperatures at a European scale at depths of between $500 \mathrm{~m}$ and $3000 \mathrm{~m}$ were published, as well as an additional map at $5000 \mathrm{~m}$. In the second atlas, which was produced in 1988 (Haenel \& Staroste, 1988), Lokhorst \& Van Montfrans (1988) provided a dataset of temperature values in 338 wells. However, they did not give an indication of the spread of these values. In this atlas, the isodepth maps for the Netherlands were at a depth of $500 \mathrm{~m}$. Only two maps were made on a European scale, showing depths of $1000 \mathrm{~m}$ and $2000 \mathrm{~m}$. However, some more geothermal energy-orientated maps were also provided, showing geological layers with a geothermal potential (i.e., Lower Cretaceous, Lower Triassic and Upper Permian).

The third atlas (Hurtig et al., 1992) presented the most detailed dataset so far for the Netherlands, which was based on the compilation of Ramaekers (1992). In this atlas, the temperature dataset for onshore the Netherlands was composed of 334 corrected bottom hole temperatures (BHT) and 53 drill stem test (DST) temperatures. The detail of the temperature values used for each depth gives a relatively steady number of around 300 values until $2000 \mathrm{~m}$, decreasing to about 150 values at $3000 \mathrm{~m}$ and finishing with only two values at $5000 \mathrm{~m}$. The isodepth temperature maps are only at the European scale for this atlas as no country description was made, reflecting the fact that this atlas was primarily a thermal atlas and not geothermal energy-orientated. The two data values given at $5000 \mathrm{~m}$ reveal that the maps were made using extrapolation from shallower values. The drawing of the temperature isolines was carried out 'taking the tectonic setting as background information', which seems to imply hand-drawn maps. In the latest atlas (Hurter \& Haenel, 2002), the dataset of Ramaekers (1992) is reused by referring to the work of Van Doorn \& Rijkers (2002), which incorporates 464 wells of the on- and offshore dataset of Ramaekers (1992). In this latest atlas, temperature maps were generated by using contouring algorithms, which shows to be a major improvement. However, a manual intervention is still made on the European temperature maps to warrant a correlation between the different sources, as each country generates its own data. To ensure the interpolation remains precise, the isodepth temperature maps are restrained to the depths that have high value densities (i.e., $1000 \mathrm{~m}$ and $2000 \mathrm{~m}$ ). Just like in the atlas of Haenel \& Staroste (1988), the temperature of the geological layers of geothermal interest, such as the Lower Cretaceous and Lower Triassic, are presented. 
In parallel to these European projects, some national and regional projects have been conducted. The work of Rijkers \& Van Doorn (1997) is an update of the 1988 atlas (Haenel \& Staroste, 1988), and here, the isodepth temperature maps are more precise due to a smaller scale. The updates are mainly related to the interpolation of the temperature on geological interfaces identified as potential reservoirs for geothermal energy. On a more regional scale, the work of Van Balen et al. (2002) and more recently Luijendijk et al. (2011), has provided both values and interesting discussion relating to the Roer Valley Graben. The dataset of Van Balen et al. (2002), used together with the shallow values of Van Dalfsen (1983), have been presented and used by Verweij (2003) to characterise the onshore temperature in the Netherlands. Recently, TNO led a number of projects to implement the onshore dataset in the Netherlands (e.g., Boxem, 2010) and to provide reliable information and correction on the temperature measurements in boreholes (Vermooten et al., 2004).

The most recent temperature map presenting the whole Dutch onshore area was published in Lokhorst \& Wong (2007). This map, which shows temperatures at a depth of $2000 \mathrm{~m}$ (Fig. 1), was made using an interpolation technique, but unfortunately it does not take into account the geology and the differences of thermal conductivity.

\section{Temperature data}

\section{Types of available temperature measurements in boreholes}

Onshore temperature measurements in the Netherlands have been collected from oil and gas boreholes. These temperatures include three main types of measurements:

- Thermometry is a continuous temperature measurement, but in oil exploration boreholes it is used to monitor cementation behind the borehole casing. Since the cementation reaction is exothermic, in-situ temperatures are much higher than equilibrium values. Correction should be possible but practically, this requires the use of parameters that are unavailable (e.g., time between cementation and measurements, cementation thickness, type of cement, etc.).

- The Drill Stem Test (DST) is a procedure used to test a formation (e.g., pressure, temperature, permeability, etc.) in the borehole by pumping the surrounding fluid. By definition, the pumped fluid is in thermal equilibrium with the surrounding formation but some thermal disturbance can occur during the rise from the reservoir to the surface (e.g., Hermanrud et al., 1991; Steffensen \& Smith, 1973; Vermooten et al., 2004). The DST temperatures are very close to the formation temperature (within $\pm 2^{\circ} \mathrm{C}$ ). However, certain circumstances can modify the precision of the temperature measurements (e.g., pressure drop during flow period, sensor accuracy, the measuring of temperature measured during

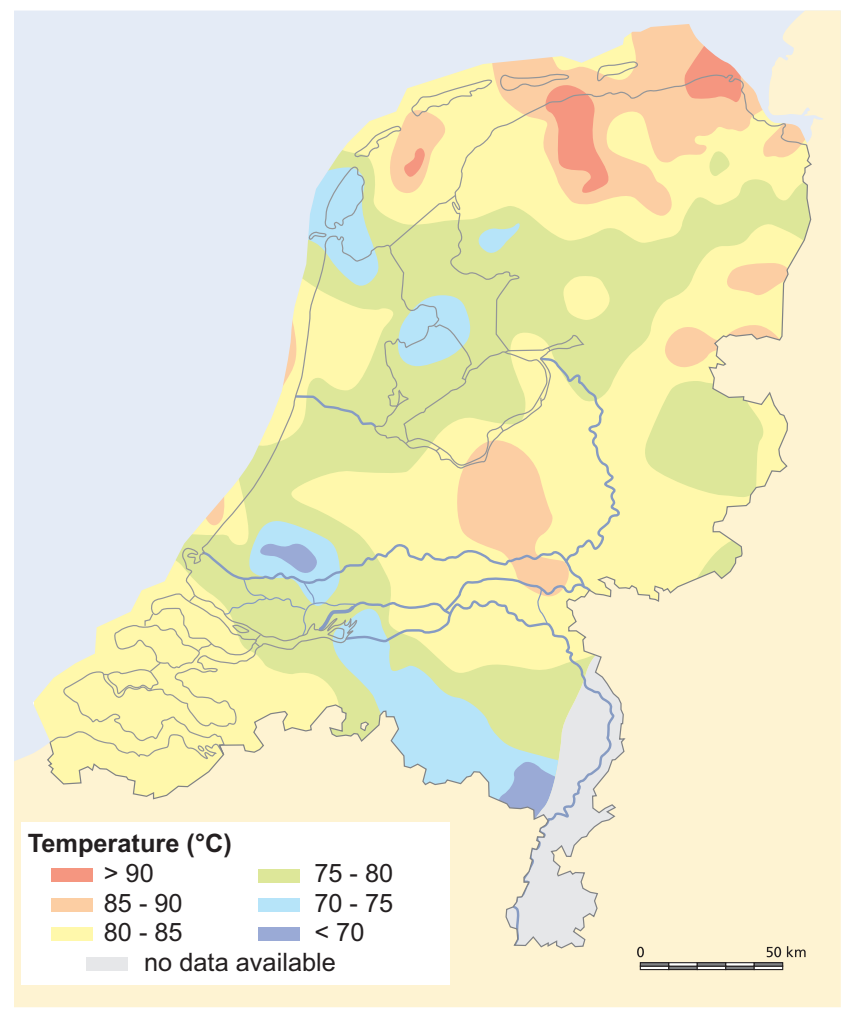

Fig. 1. Temperature map at 2000 m (modified after Lokhorst \& Wong, 2007).

flow or build-up). These possible modifications increase the measurement error of the DST values to $\pm 5^{\circ} \mathrm{C}$.

- The BHT (Bottom Hole Temperature) is a side-product of most logging tools. It corresponds to the maximum temperature recorded during logging - theoretically (but not necessarily) the temperature at the bottom. Before logging operations begin, a borehole is cleaned by a circulation of mud to remove cuttings. The mud is injected at a temperature that is usually colder than that of the borehole itself. Because the time elapsed between the end of the mud circulation and the measurement of temperature is usually so short (typically only a few dozen hours), the measured temperature is not at equilibrium, and a correction is required (see below).

Here we compile a datasets consisting of DST formation temperatures and corrected BHTs.

\section{Correction methodologies of the Bottom Hole Temperature (BHT) measurements}

The thermal perturbation caused by drilling is mainly related to the circulation of fluids. Two circulations appear to be responsible for the modification of temperature in the well: (a) the circulation during drilling; and (b) the circulation used to clean the borehole from the remains of cuttings and before logging operations. As the BHT values are measured at the deepest part of the well, the major thermal perturbation is the fluid circulation used to clean the borehole. The longer the fluid 
circulates, the higher the degree of disturbance. Unfortunately, information regarding the duration of the cleaning circulation is rarely recorded in the well logs (the source of our initial dataset). In order to avoid estimations and assumptions of this circulation time, the corrections used in this study therefore concentrate on the return to equilibrium, and not on the perturbation itself.

Practically, in order to provide a consistent dataset of corrected BHT values (referenced as BHTx), we correct the BHT measurements using two main types of correction. The first type uses an analytical methodology for correction. For this model, we have chosen the Instantaneous Cylinder Source (ICS). The descriptions and the reasons for the choice of the ICS correction can be found respectively in Goutorbe et al. (2007) and Bonté et al. (2010). The second is a statistical correction, known as the AAPG correction. The description of this AAPG correction is available in Blackwell \& Richards (2004) and a more recent study using French BHT data can be found in Garibaldi (2010). This secondary correction gives a slightly less accurate result but also requires less input to be performed than the ICS correction. For both of these reasons, the AAPG correction has been done only on the BHT values, which had insufficient supporting data to perform the ICS correction (e.g., elapsed time after circulation stopped).

In order to discriminate between the uncorrected BHT measurements and the corrected BHT values, the BHT values that have been analytically corrected with the ICS method will now be called BHTx_ICS and the BHT values statistically corrected using the AAPG method and correlated to the BHTx_ICS (see the analytical correction section below) will be called BHTx_AAPG.

\section{Analytical correction of the BHT}

Existing correction methods have been synthesised by Goutorbe et al. (2007). The different methods result from different hypotheses on the geometry (e.g., line source method, cylinder source method and two-component model), and on the time evolution (e.g., continuous or instantaneous cooling). Unlike the line source method, the cylinder source method can account for a finite width perturbation, while the two-component model additionally recognises the different thermal properties between the borehole mud and surrounding rocks. Borehole radius is used in the equations. In the continuous case, the cold perturbation is defined with a certain time scale (mud circulation time is taken into account). Line source and cylinder source methods can be performed on a continuous or instantaneous perturbation time scale. The two-component model takes into account the time scale of the perturbation.

The methods compiled by Goutorbe et al. (2007) are the ICS (Instantaneous Cylinder Source), the ILS (Instantaneous Linear Source), the CLS (Continuous Linear Source), the CCS (Continuous Cylinder Source), the Horner (a simplified version of the CLS method) and the two-component model. The two-component model, however, requires a number of parameters that are rarely available, such as the thermal properties of mud. As a result, we have chosen to reject this method.

We have chosen the ICS method for this study in order to create the most reliable dataset possible and to keep the highest number of corrected BHT values (Bonté et al., 2010). The weakest aspect of the BHT correction is the uncertainty. It is generally accepted to have an uncertainty on the BHT correction of $\pm 5-10{ }^{\circ} \mathrm{C}$ (e.g., Brigaud, 1989; Goutorbe et al., 2007).

\section{Statistical correction of the BHT}

To complete the dataset of the BHTx_ICS, we applied a statistical correction of the BHT measurements without 'shut-intime' and/or with a single value per depth. The AAPG statistical correction method is based on the database acquired in the early 1970s during the Geothermal Survey of North America (GSNA). This vast database $(10,000$ BHT from the 20,000 boreholes in the USA, Canada and Mexico) was compared to the DST available in 0klahoma (Harrison et al., 1983) to obtain a statistical correction. Deming (1989) defined three sets of coefficients that applied: the two first sets are precisely defined for West Texas and Louisiana, and the third dataset is defined as an average that can also be used independently of the two others. Garibaldi et al. (2010) compared the result of the AAPG methods to the ICS analytical method and obtained a very acceptable bulk average difference of $3.7^{\circ} \mathrm{C}$.

The BHT dataset used to perform the calculation of the BHT_ICS has also been corrected with the AAPG method (Deming, 1989) using the average coefficients (this intermediate correction is hereafter named BHTx_AAPGini). When these two datasets (with each dataset comprising 1286 values) are plotted on a chart showing temperature vs. depth (Fig. 2a), it is possible to identify a shift between them with a bulk average difference of $5.64^{\circ} \mathrm{C}$. This shift is mathematically highlighted by the average thermal gradient. The average thermal gradient for the BHTX_ICS dataset is $\mathrm{T}=0.0302 \mathrm{z}+12.776$ (where $\mathrm{T}$ is the temperature in degrees Celsius at the depth $\mathrm{z}$ in meters), while the average thermal gradient for the BHTx_AAPGini is $\mathrm{T}=0.0321 \mathrm{z}+12.419$. Compared with the BHTx_AAPGini, the surface temperature is slightly higher $\left(0.357^{\circ} \mathrm{C}\right)$ for the BHTx_ICS but the gradient is lower $\left(-0.0019^{\circ} \mathrm{C} / \mathrm{m}\right)$. This difference induces higher temperatures at a deeper level. The reason for such differences lies within the generalised approach of the AAPG method. In order to correct the BHTx_AAPGini and ensure the dataset is regionally related to the more reliable BHTx_ICS data, we applied a depth-dependent correction to the dataset. The result of this correction is presented in Fig. 2b; here, the BHTx_ICS and the BHTx_AAPG now show a homogenous result. The bulk average difference is $3.28^{\circ} \mathrm{C}$. This BHTx_AAPG dataset is not used because it has already been corrected using the ICS method. However, we performed this secondary correction on 

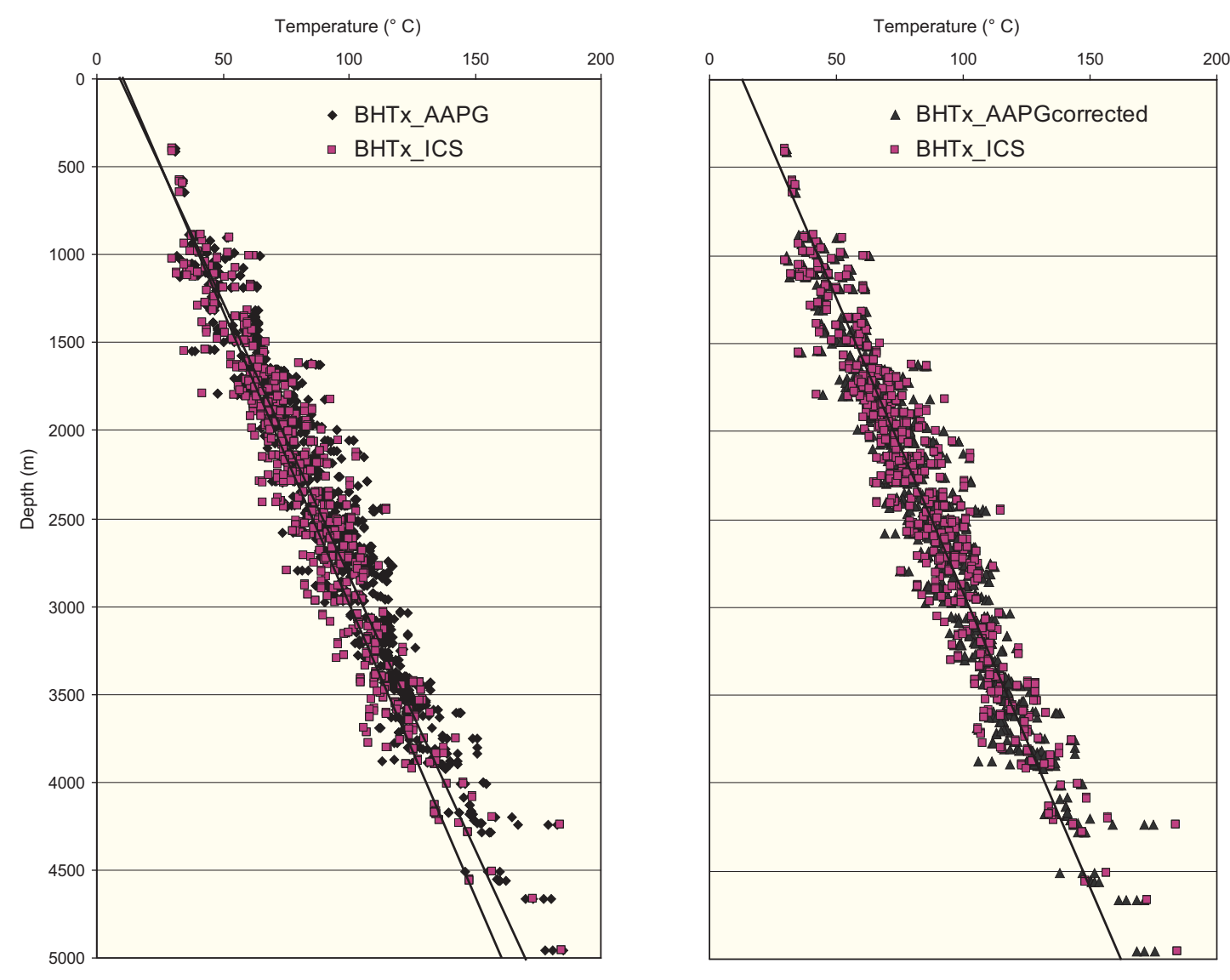

a.

b.

Fig. 2. Comparison of the temperature vs. depth values between the results of the AAPG method and the ICS method for the same initial BHT dataset. a. ICS method vs the standard AAPG method. Grey square: BHTX_ICS. Black diamond: BHTx_AAPG; $b$. ICS method vs the standard AAPG method for correcting regional variations (see text for explanation).

the BHTx_AAPGini, which could not have been corrected using the ICS method alone. We thus obtained a complementary dataset, named the BHTx_AAPG dataset, which has a good reliability. The BHT dataset, corrected with the AAPG correction, is suitable for regional interpretation; however, it cannot be considered as reliable for studies requiring individual measurements.

\section{Alternative modelling correction method}

The recent work of Luijendijk et al. (2011) presents a very interesting correction method. Based on the two-component model presented in Goutorbe et al. (2007), it simulates the borehole temperature during drilling and the following return to equilibrium. To do this, it uses a numerical finite difference model to solve the $2 \mathrm{D}$ heat flow equation. The results obtained are very precise with an uncertainty range of $\pm 5{ }^{\circ} \mathrm{C}$, i.e., half of that assumed with the ICS method that we used. However, for the purposes of our work, and even accepting that the precision of the correction is higher, this method nonetheless requires too many parameters to be used effectively at a country scale on thousands of uncorrected data. In addition, the high number of necessary parameters required to perform this correction restrains the number of corrected data generated given the dataset available for this work. Our conclusion is that this method would be of great interest for a study with a more limited regional extension.

\section{Temperature dataset in the Netherlands}

The Dutch territory is covered by numerous wells from exploration and exploitation of oil and gas. The Central Netherlands Basin, the Texel-IJsselmeer High, the Friesland Platform, the Lauwerszee Trough, the West Netherlands Basin, and the southern part of the Lower Saxony Basin close to the Gronau Fault Zone (see Fig. 3 for localities) have a very high well density. These areas correlated with areas of exploitation and where exploitation permits for hydrocarbons have been issued (Fig. 4; De Jager, 2007). Other areas usually have lower well density. From all available wells, thousands of uncorrected BHT measurements have been regrouped by Boxem (2010), the PressureSNS projects (Simmelink et al., 2003, 2008) and the internal TN0 database in order to create a single dataset of BHT measurements. To complete the dataset a number of wells were added for this study, for instance, the newly drilled Luttelgeest-01. After removal of duplicates and unrealistic values, we obtained 


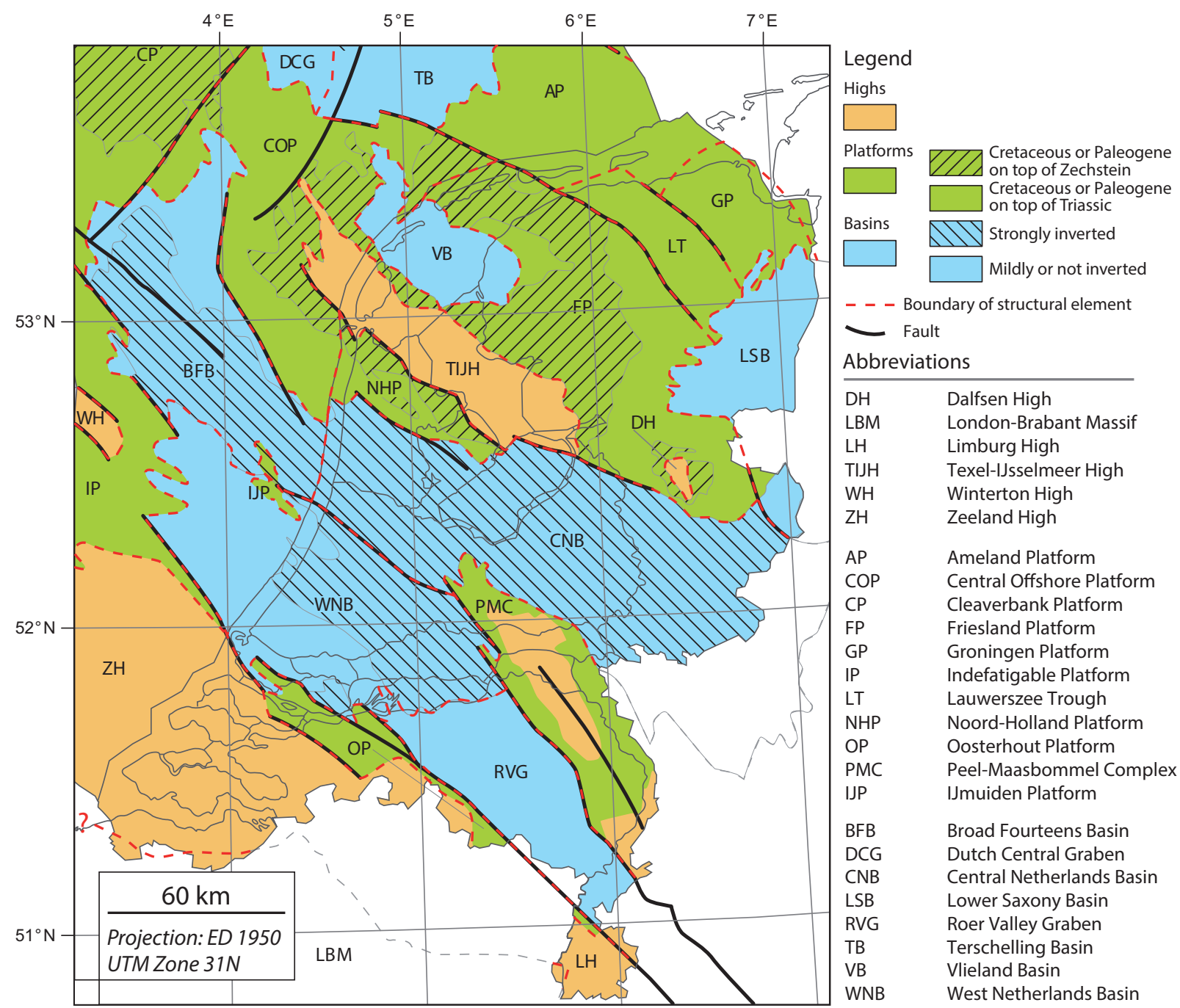

Fig. 3. Map of the structural elements of the onshore Netherlands showing Mid-and Late Kimmerian (Jurassic and Early Cretaceous) basins, highs, and platforms (after Kombrink et al., this issue).

a dataset of 4276 BHT measurements distributes over 456 wells (Fig. 4). We also used 52 DST measurements in 24 wells, which considering the small measurement error $\left(<5^{\circ} \mathrm{C}\right)$, can be used without correction. The whole dataset of both BHTs and DSTs was corrected for well deviation and all the temperature maps in this paper show the corrected depth and the projected XY position.

\section{Corrected datasets for the Netherlands}

The BHT measurements are first corrected following the ICS method described by Goutorbe et al. (2007). In order to obtain a higher number of values and a good coverage of the area under consideration, the values that are not used by the ICS method are corrected with the statistical AAPG method (Deming, 1989), which requires less input. After the ICS correction two data classes remain. The first class contains the data rejected by the ICS correction because of lack of information on 'shut-intime' and/or borehole size; in this case the leftover dataset is cleared to keep only a single data at a given depth. The second class is the data with a single value at a given depth. Following the AAPG correction method, we performed a secondary correction on this dataset, calibrated on the BHTx_ICS data, to obtain a definitive BHTx_AAPG (see above for details).

The result of the ICS correction is a dataset of 412 BHTx_ICS in 218 wells, while the AAPG correction creates 829 BHTx_AAPG in 363 wells and the DST measurement consists of 52 values in 24 wells. As some values from different sources are recorded in the same wells, the overall number of wells with at least one temperature value is 454 and the total number of temperature values is 1293 . The temperature values range from $200 \mathrm{~m}$ to $5800 \mathrm{~m}$ in depth, although the vertical distribution is not homogenous. Over $90 \%$ of the temperature values are between $500 \mathrm{~m}$ and $3500 \mathrm{~m}$ depth (Fig. $5 \mathrm{a}$ ), whereas $8.5 \%$ of the values are between $3500 \mathrm{~m}$ and $4500 \mathrm{~m}$. Within the larger group, it is noticeable that the BHTx_ICS values are between $1500 \mathrm{~m}$ and $3500 \mathrm{~m}$, while the BHTx_AAPG values are generally shallower (between $500 \mathrm{~m}$ and $1500 \mathrm{~m}$; Fig. 5a). Over the entire depth range, the DST values constitute only $1.5 \%$ of the total temperature values used. 


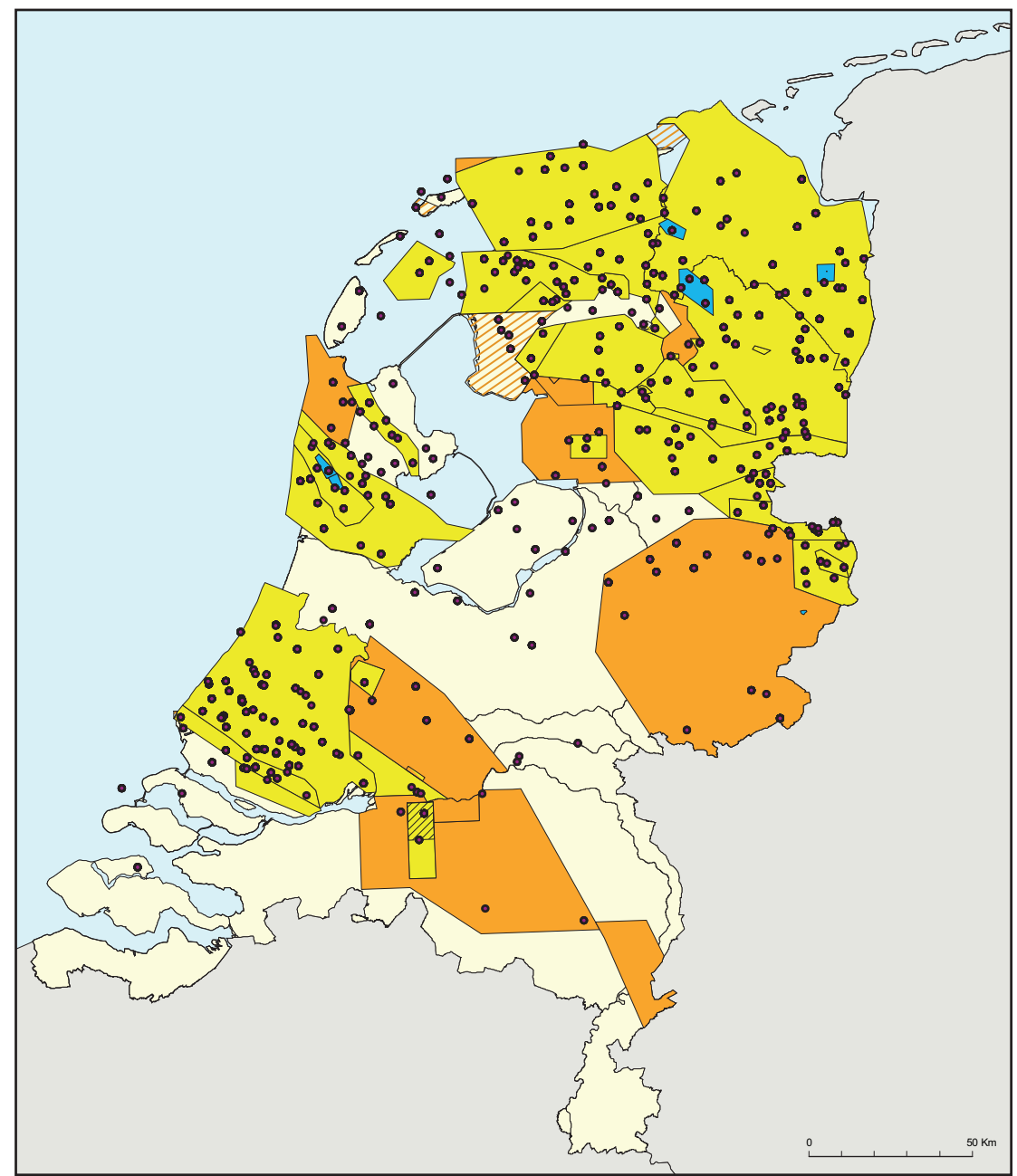

Exploration, production and storage permits for hydrocarbons

Situation on January 1st, 2011

Production permit

Exploration permit

Requested exploration permits

Open area, continental shelf and territory

Storage permit
The spatial distribution of the BHTx_AAPG, BHTx_ICS and DST are closely related to the high and low density areas where BHT measurements are available (Fig. 5b). The covered areas with corrected BHT and DST values are mostly situated within the limits of hydrocarbon exploitation- and exploration permits limits, such as the Central Netherlands Basin, the North Holland Platform, the Friesland Platform, Groningen High, Lower Saxony Basin and the West Netherlands Basin. In the depth interval from 500 to $3500 \mathrm{~m}$ the concentration of values is maximal (Figs 6a-c), whereas the data density decreases rapidly at greater depths (Figs 6d-f).

\section{Dataset for modelling}

The combined dataset of corrected BHT and DST temperatures includes 1293 values with reasonable uncertainties. The corrected BHTx_ICS has an uncertainty of $\pm 10^{\circ} \mathrm{C}$ (Bonté et al., 2010). Given the regional calibration of the AAPG correction, the BHTx_AAPG can be used with the same degree of uncertainty as the BHTx_ICS. The DSTs are usually considered to have an error related to the precision of the thermometer; here we use the earlier mentioned error of $\pm 5^{\circ} \mathrm{C}$. The whole dataset gives an average gradient of $31.3^{\circ} \mathrm{C} / \mathrm{km}$ and a surface temperature of $10.1^{\circ} \mathrm{C}$ (Fig. 5a). The maximum variation around the average trend is about $25^{\circ} \mathrm{C}$. At depths greater than $4000 \mathrm{~m}$, both BHT and DST data indicate a sudden shift toward higher temperatures that seem to deviate from the overall trend (Fig. 5a).

\section{D Tectonic-thermal modelling}

In areas without wells, existing 3D geothermal models for basins typically use geo-statistical interpolation of temperatures and temperature gradients measured from wells (e.g., Bonté et al., 2010) as well as compilations of thermal gradients and heat flows in maps. Temperature interpolation in such models generally lack a physical underpinning, which can result in erroneous temperature predictions as geostatistical interpolation results can differ significantly from model-based approaches that include thermal properties and processes (e.g., Van Wees et al., 2009). The temperature in such a model is a function of boundary conditions including surface temperature, basal heat flow and thermal properties such as thermal conductivity and radiogenic heat production, and which extends in depth to include the whole lithosphere, thus incorporating the effects of thermal properties and transient processes in crust and lithosphere (e.g., Cloetingh et al., 2010). 

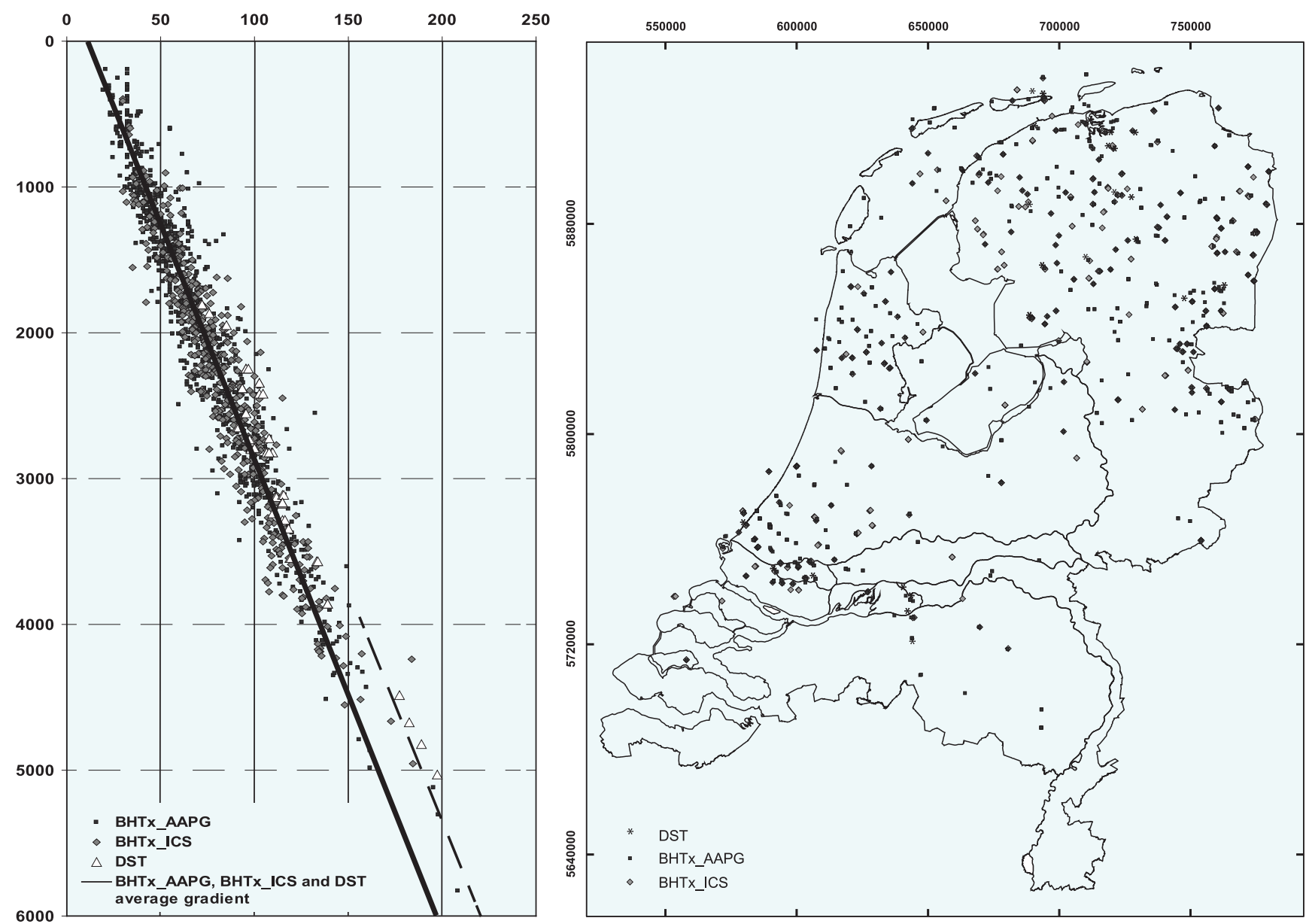

a.

Fig. 5. DST and Corrected BHT dataset. Black square: BHTx_AAPG. Grey diamond: BHTx_ICS. White triangle: DST. Solid black line: general trend. Dashed black line: deep trend. a. Temperature vs. depth chart; $b$. Horizontal distribution of the data.

\section{The modelling: method and methodology}

\section{The modelling methodology}

In the 3D model, we aim to incorporate the effects of variations in petrophysical parameters (thermal conductivity and radiogenic heat production) and the transient effects of vertical tectonic motions in terms of sedimentation and crustal deformation affecting temperature. To incorporate these effects, the model solves the transient 3D temperature equation:

$$
\frac{\partial \mathrm{T}}{\partial \mathrm{t}}=\frac{1}{\rho \mathrm{C}_{\mathrm{p}}}[\nabla \cdot(\mathrm{k} \nabla \mathrm{T})+\mathrm{A}]-\mathrm{v}_{\mathrm{z}} \frac{\mathrm{dT}}{\mathrm{dz}} \quad \text { with } \nabla=\left(\frac{\partial}{\partial \mathrm{x}}, \frac{\partial}{\partial \mathrm{y}}, \frac{\partial}{\partial \mathrm{z}}\right)^{\mathrm{T}}
$$

where $\mathrm{T}=$ temperature, $\rho=$ density, $\mathrm{C}_{\mathrm{p}}=$ specific heat, $\mathrm{k}=$ thermal conductivity, $\mathrm{A}$ = radiogenic heat production and $\mathrm{v}_{\mathrm{z}}$ is vertical velocity in a 'eulerian' reference frame in which the sedimentwater (topographic) interface corresponds to $z=0$. Therefore, $\mathrm{vz}$ is related to accumulation (i.e., addition) or erosion (i.e., removal) of sediment and vertical motion in the crust related to stretching of the lithosphere. For the transient numerical modelling of the temperature evolution of equation (1), a 3D explicit 3-step Runge-Kutta finite difference approach was used (Verwer, 1977) with a finite volume approximation. Transient thermal effects relate to vertical velocities in the 3D grid, changing surface temperature conditions, and changes in material properties. In solving the temperature equation, we choose to incorporate vertical velocities in accordance with the latest stage of the basin evolution from $t_{b}$ (in Ma) to the present day. Typically, $t_{b}$ is in the order of up to tens of million years, depending on the observed vertical sediment accumulation and erosion rates. For $t_{b}$, the sedimentation, erosion and associated lithosphere deformation is determined by adopting backstripping and forward modelling (cf. Van Wees et al., 2009). The resulting velocity field is incorporated in the thermal modelling. The surface temperature varies in accordance with an arbitrary temperature evolution from $t_{b}$ to present day, whereas the base of the lithosphere remains fixed (cf. Van Wees et al., 2009).

To incorporate spatial variability in properties, velocities and initial lithosphere thickness, the model is a regular 3D grid, with grid spacing along the $\mathrm{x}$ and $\mathrm{y}$ axes fixed at $1 \mathrm{~km}$, while 
the grid spacing in direction $\mathrm{z}$ varies with depth. Up to a fixed depth of $6400 \mathrm{~m}$, well below the Mesozoic sediment-basement interface, the grid spacing was set at $200 \mathrm{~m}$. Below this, depth spacing was set at a significantly wider spacing of $1000 \mathrm{~m}$, extending to the base of the lithosphere.
The thermal properties and associated geometry of the basin and underlying crust have been chosen in accordance with the present-day configuration. The thermal properties have been determined in accordance with a differentiated layered lithology affected by compaction and are capable of correctly reproducing
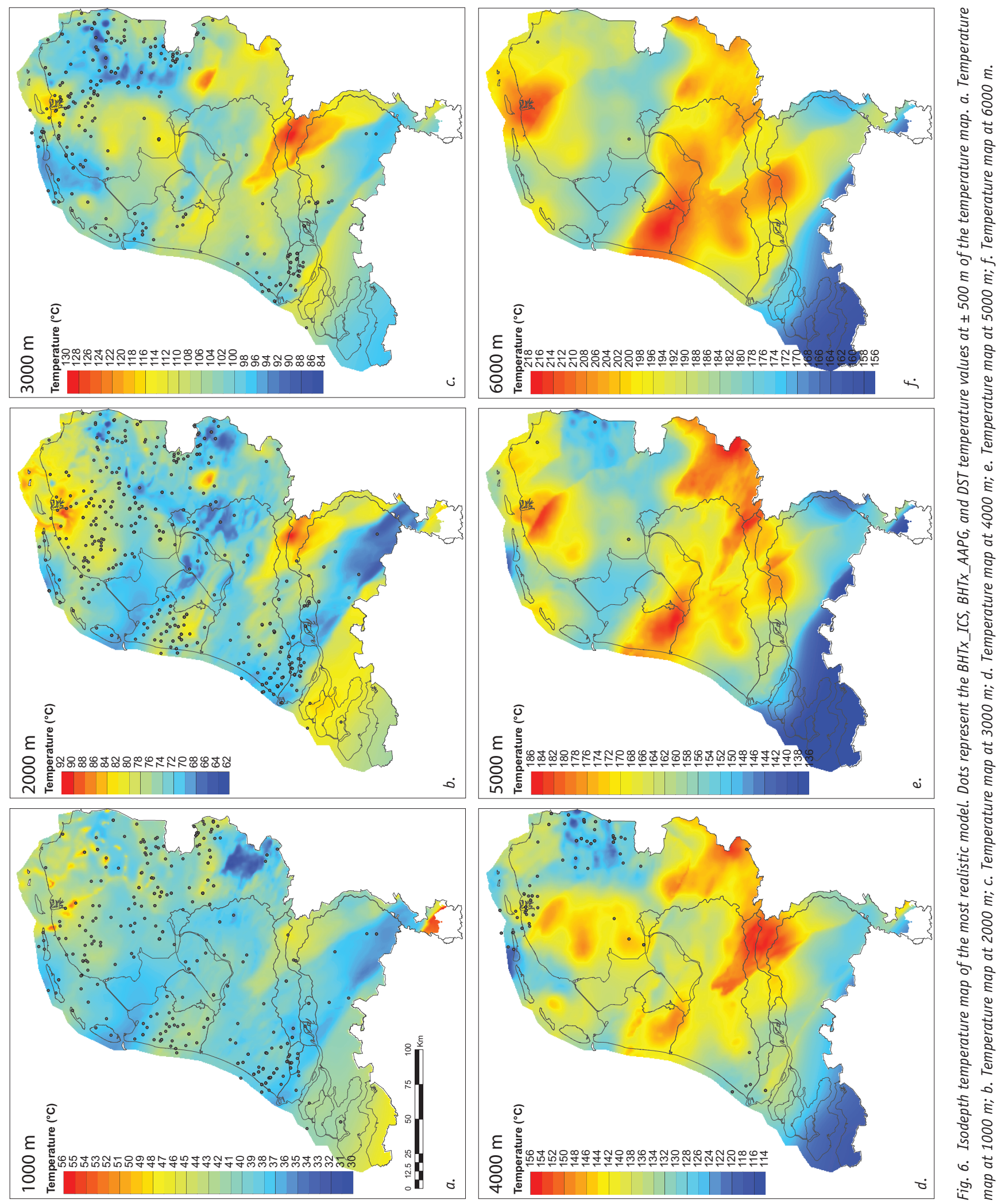
the effects of highly conductive salt layers and anisotropic thermal conductivity of intra-formational sediment layering. The thermal properties have not been changed through time from $t_{b}$ to the present day. The effects of these alterations are minor compared to the effects of variation in vertical velocity and surface temperature, and result in significant increase in numerical performance.

\section{Calibration of temperature data}

The model is iteratively calibrated to a best-fit with the corrected temperature data in the wells, which typically takes less than five runs to achieve. This iteration is schematically shown in Fig. 7. At the start of the model, a 1D steady state geothermal solution is performed at each well location (e.g., Van Wees et al., 2009), calibrated to the measured well data by varying the initial lithospheric thickness and crustal heat production within certain bounds. The temperature data used are the BHTx_ICS, the BHTx_AAPG, and the DST, as described in section 3.

If more than one single well data point occurs in a grid column, the data is grouped and treated jointly in order to obtain a minimised average misfit between the analytical model and the observed temperatures. Subsequently, the 1D analytical solutions based on these points are smoothed in terms of lithospheric thickness and crustal heat production and used to compute the $3 \mathrm{D}$ temperature field adopting the transient solution. The model misfits observed in the 3D solution are next used in a new step to improve the 1D model prediction. To this end, the Broyden iterative scheme (Press et al., 1988) is used, enabling the effects of $3 \mathrm{D}$ temperature dependency to be taken into account.

\section{Basin structure and tectonic setting}

The assessment of thermal properties and tectonic setting has considerable influence on the modelled temperature results. We therefore briefly outline the geological history of the major structural elements in the Netherlands and their associated stratigraphic units.

The basement, on which the sedimentary cover of the Netherlands rests, mainly consists of (Eastern) Avalonian crust (Pharaoh et al., 2010). This Gondwana-derived micro-continent consolidated with Baltica during the Caledonian orogenic cycle by closing the Tornquist 0cean in the Late Ordovician. In the Netherlands, south west of the West Netherlands Basin, the Avalonian crust forms the stable London Brabant Massif. This massif is covered by Cambro-Silurian shales that became deformed in low grade metamorphosed slates during the late Silurian-early Devonian, in response to the accretion of Baltica (including Avalonia) and Laurussia.

North-east of the London-Brabant Massif, no information on the presence of pre-Variscan basement is available. Here, the sedimentary basin that covers the onshore part of the Netherlands developed in Devonian and Carboniferous times in response to lithospheric stretching and Late Carboniferous flexural subsidence associated with the Variscan orogenic cycle (Kombrink et al., 2008). The Devonian basin fill is composed of detritic sandstones. Unfortunately, given its depth, the outline of this very early basin is mostly unknown. However, as the sand-prone lithology of the basin fill has a thermal conductivity value close to the one of the basement, this uncertainty has little impact on the temperature distribution. For this reason, we chose not to take this stratigraphic unit into account. The following Lower Carboniferous unit consist of a system of isolated carbonate platforms that are associated with the closure of the Rheic Ocean's back-arc domain. In the Late Carboniferous (Silesian), the Variscan thrust front moved northwards due to the collision between Gondwana and Laurentia, thereby placing the Netherlands in a foredeep basin position north of the Variscan orogen. As the foredeep evolved, tectonic accommodation space increased significantly and the accumulated clastic deposits reach a thickness of $4000 \mathrm{~m}$, which is much thicker than any younger overlying unit. The Silesian rocks are
Fig. 7. Work flow diagram of the Tectonic Heat Flow model use for the present day subsurface temperature.
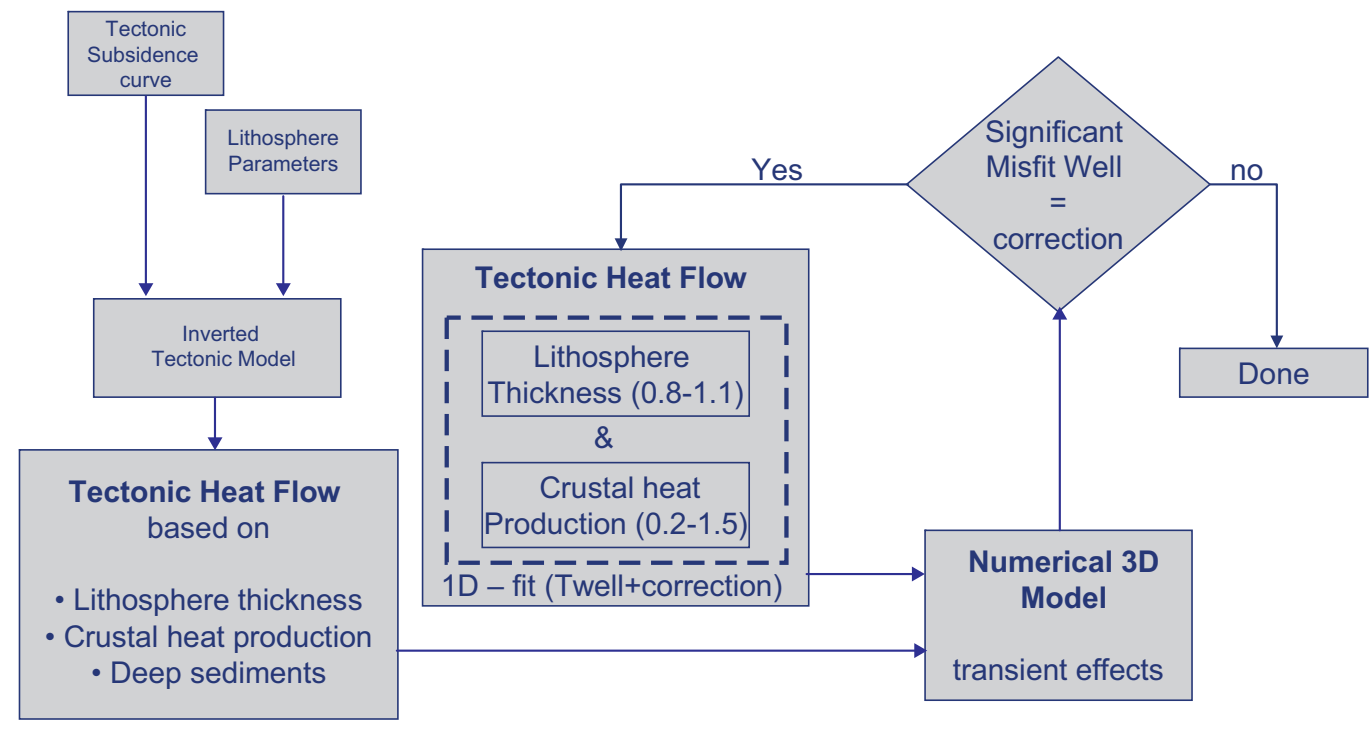
mainly siliciclastic and were laid down in depositional environments ranging from fluvial floodplains to lacustrine/marine, depending on the position in the basin. The lithological composition is dominated by shale that has a thermal insulation effect, which is enhanced by the presence of coal that reaches a proportion as high as $2.1 \%$. As the Variscan orogen collapsed, a thermal sag developed at the beginning of Permian, creating the Southern Permian Basin (Ziegler, 1990; Van Wees et al., 2000). In the Netherlands, Permian deposits are mainly represented by siliciclastic and marine evaporitic sediments of the Rotliegend Group and Zechstein Group, respectively. The evaporites of the Zechstein Group are dominant in the northern half of the Dutch subsurface, but are lacking in the south. As a result of this disparity, the character of the Zechstein stratigraphic unit shows strong lateral differences. In the south, the layers remain relatively homogenous in thickness and are only impacted by compaction, while in the north, salt flow has generated numerous diapirs. Evidence of Early Permian magmatism was identified in several Dutch wells, particularly in the eastern part of the Texel IJsselmeer High, but the extension of the magmatism remains uncertain. In the Triassic, fault-bounded depocentres were formed that have been interpreted as epicontinental clastic sedimentary basins with some thinly developed evaporites. Following the late Triassic structural evolution, during the Jurassic, smaller faultbounded basins and highs developed. The Early Jurassic is dominated by relatively continuous marine shale deposition. Eventually, rifting in the North Sea led to the formation of a dome, the centre of which is localised between Scotland and Norway. This doming led to uplift that generated strong erosion in the north of the Dutch offshore and non-deposition in the southern part of the country. In the Late Jurassic and Early Cretaceous, differential subsidence due to basin fragmentation led to a highly dispersed pattern of fluvial to shallow marine siliciclastic sedimentation. By the end of the Cretaceous, the basin infilling becomes predominantly calcareous. During the Late Cretaceous and Cenozoic, the Alpine orogeny transmitted compressional stresses to the Netherlands, leading to a period of intermittent inversion tectonics with uplift and the erosion of previous basin fills. Cycles of sand-clay deposition are often associated with pulses of convergence and subsidence, which caused depositional environments to change from coastal plain to shallow marine, respectively. The Quaternary succession predominantly consists of siliciclastics laid down by various fluvio-deltaic, glacial, and coastal depositional systems.

\section{Modelling input}

In order to perform the modelling, a structural model of the lithosphere and basin fill needs to be defined, against which the appropriate thermal properties can be applied. The structural model considers four major layers: the sediments, the upper crust, the lower crust and the mantle lithosphere. The lower boundary of the model - the base of the lithosphere - is fixed at a temperature of $1330^{\circ} \mathrm{C}$, while the depth beneath the Netherlands can vary between approximately $80 \mathrm{~km}$ and $125 \mathrm{~km}$, with an estimated average of $100 \mathrm{~km}$ (Artemieva et al., 2006). This limit in temperature is related to the changes in the type of heat transfer in the mantle from convective to advective (Sleep, 2005; Jaupart \& Mareschal, 2007). The crustal thickness has been obtained from CRUST07 (Tesauro et al., 2008), and has a typical value of around $32 \mathrm{~km}$. The crust is subdivided into a highly radiogenic upper crust (UC) and a less radiogenic lower crust (LC) (e.g., Van Wees et al., 2009). The default thermal properties for the lithosphere and crust (e.g., Cloetingh et al., 2010) have been listed in Table 2 and correspond to the initial values used for the model. After several iterations, the lithospheric thickness and the heat production of the upper crust were modified (see Figs 7 and 8 for details) to fit the temperature data.

The structure of the thirteen sedimentary units considered here (see Fig. 14) is a result of the mapping project presented in the Geological Atlas of the Subsurface of the Netherlands (TNO-NITG, 2004). Several improvements have been made since this 2004 model. For instance, the Triassic has been divided into the upper and lower Germanic Trias Groups and the Quaternary has been included in the Upper North Sea Group. Sediments below the Base Permian Unconformity, which were previously referred to as 'Carboniferous and below', are now given in more detail. The latest description of the Silesian (personal communication, H. Kombrink) gives thickness values from $1 \mathrm{~km}$ in the southernmost part of the Netherlands to up to $4 \mathrm{~km}$ in the basins (i.e., West Netherlands Basin, Roer Valley Graben, and Central Netherlands Basin). The Pre-Silesian is mostly composed of limestone and has a thickness of $\sim 1 \mathrm{~km}$. Thermal properties have been defined for each of the thirteen sedimentary units (see Table 1) using the technique of mixing basic lithologies. This also honours the relatively high thermal conductivity for salt layers. Description of the mixed lithology technique, as well as the properties for the basic lithologies, is available in Hantschel \& Kauerauf (2009).

For $t_{b}$, we adopted 20 Myr (Early Miocene to present), a period that is marked by relatively moderate accumulation rates as based, for instance, on the preservation of approximately $2 \mathrm{~km}$ of sediment in the RVG in the southeast of the Netherlands. Tectonically, this period is marked by a mixture of rifting and intraplate stress-induced subsidence, which explains an increased creation of accommodation space. The mobilisation of salt in the last $20 \mathrm{Myr}$ is restricted to some individual diapirs in the northeast. Of the $>2500 \mathrm{~m}$ vertical extent of the salt diapirs, only a few hundred metres (at the most) is attributed to this period. The effects of strong palaeosurface temperature fluctuations have been taken into account in accordance with recent geochemical and geo-biological proxies (Fig. 9; Donders et al., 2009; Verweij et al., 2012). 

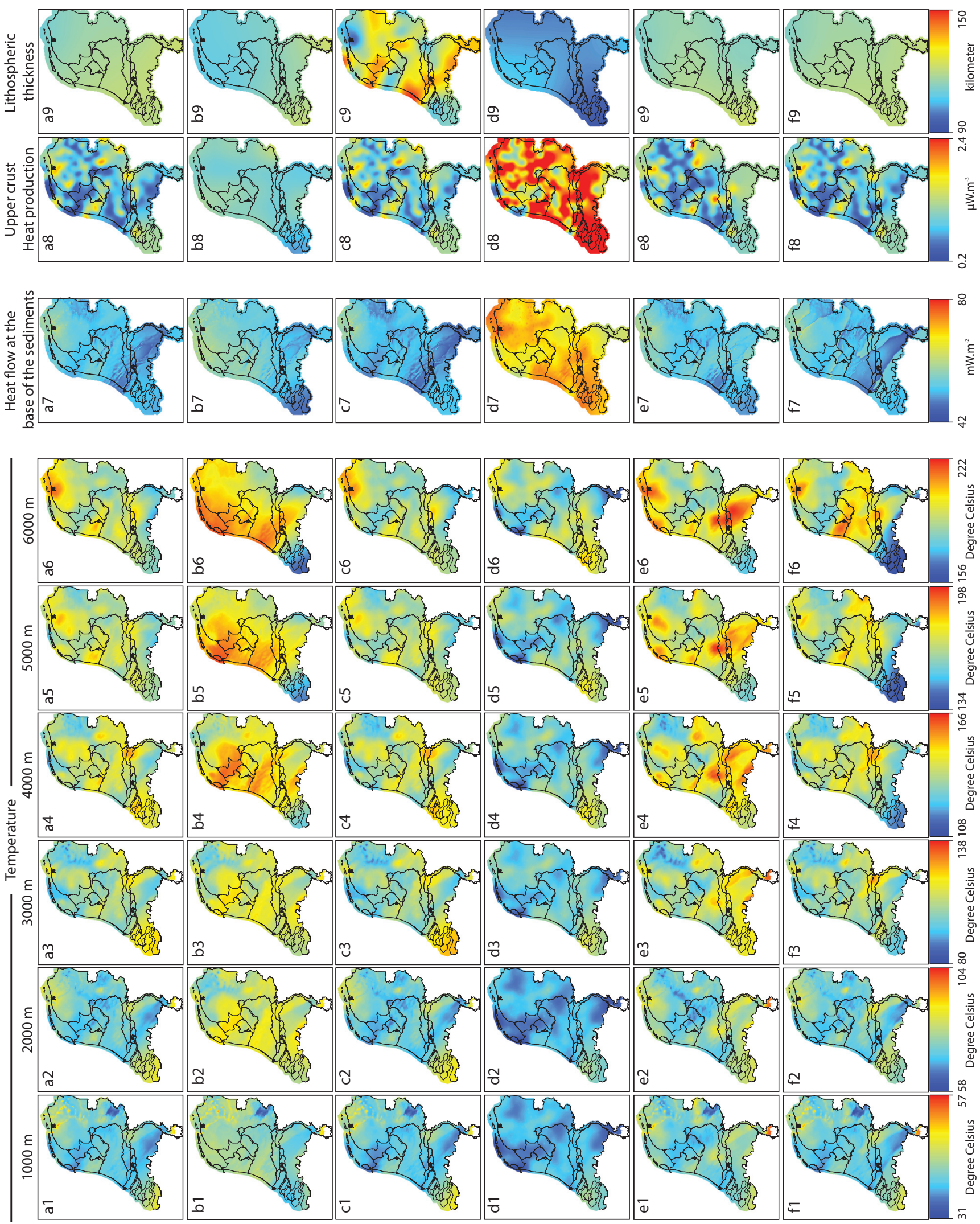

Fig. 8. Maps of the temperature models. Maps $x 1$ to $\times 6$ : isodepth temperature maps. Map x7: heat flow maps at the base of the sediments. Map x8: maps of the upper crust heat production. Map $\times 9$ : thickness of the lithosphere. For the description of each mode, see text. For description of the different model scenarios. 
Table 1. Sedimentary layers of the model.

\begin{tabular}{lllll}
\hline Layer & Period & Age min. & Age max. & Average lithology \\
\hline Quaternary & Quaternary & 0 & 2.5 & Fine- and coarse-grained siliciclastics \\
Upper North Sea Group & Cenozoic & 2.5 & 20 & Fine- and coarse-grained siliciclastics \\
Lower and Middle North Sea Groups & Cenozoic & 20 & 61.7 & Mainly coarse-grained siliciclastics \\
Chalk Group & Cretaceous & 61.7 & 99.1 & Limestone (chalk) \\
Rijnland Group & Cretaceous & 99.1 & 145 & Fine- and coarse-grained siliciclastics, marls \\
Schieland, Scruff and Niedersachsen Groups & L. Jurassic & 145 & 163.4 & Siliciclastics, bituminous shales, coal \\
Altena Group & E.-M. Jurassic & 163.4 & 203.6 & Marine shales and carbonates \\
Upper Germanic Trias Group & M.-U. Triassic & 203.6 & 246.2 & Fine-grained siliciclastics, carbonates and evaporites \\
Lower Germanic Trias Group & E.-M. Triassic & 246.2 & 251 & Fine-grained siliciclastics \\
Zechtein Group & Permian & 251 & 258 & Salt, carbonates and siliciclastics \\
Upper Rotliegend Groups & Permian & 258 & 268 & Coarse-grained siliciclastics \\
Silesian & L. Carboniferous & 268 & 330 & Fine-grained siliciclastics \\
Pre-Silesian & E. Carboniferous & 330 & 360 & Carbonates
\end{tabular}

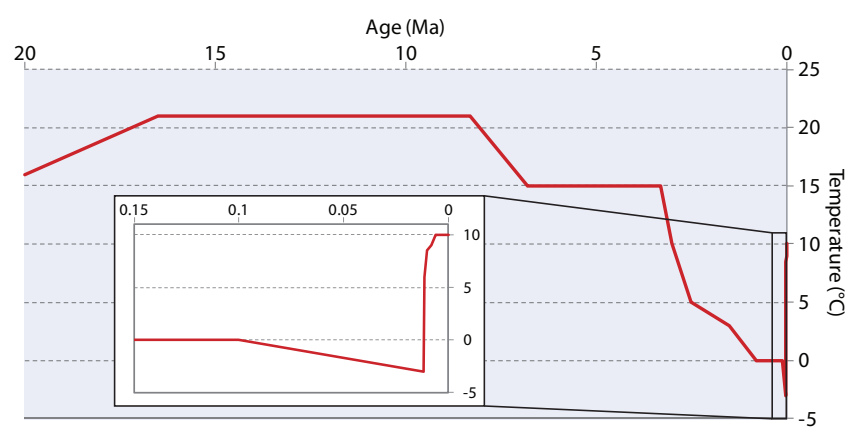

Fig. 9. Surface temperature in the Netherlands (Source: TNO).

Other scenarios with a longer duration for $t_{b}$ up to the base of the Cenozoic were evaluated, but did not result in significantly different model results.

\section{Model scenarios and sensitivity analysis}

To observe the variability of the temperature in relation to the main parameters (lithosphere thickness, heat production of the upper crust, thermal conductivity of the sediments, calibration data, and the lower part of the geometrical model), we have computed six models. These models reflect variation in the crustal heat production band width and smoothing radius, the lithospheric thickness band width and smoothing radius and the various scenarios for the sediment conductivity. All the models share the same layer definitions (Table 1), with the exception of model d, which has a unique lithology (i.e., sandstone) for all the layers, as well as the parameters for the crust and lithospheric mantle (Table 2). Figure 8 presents these six models after the fourth iteration; each row corresponds to a model. Model a was chosen as the reference and all others are compared to this 'reference model'. The models can be summarised as follows:

- Model $\mathrm{a}$ is identical to the best model (model $\mathrm{f}$ ), with the exception of the deepest part of the geometrical model, where the Silesian and pre-Silesian are combined into one Carboniferous layer.

- Model $b$ tests the smoothing radius for the heat production of the upper crust, which is increased to $50 \mathrm{~km}$ (10 km for model f).

- Model c tests the lithosphere thickness variation, which is increased and can vary between 0.6 and 1.4 (between 0.8 and 1.2 for model $\mathrm{f}$ ).

- Model d tests the influence of the lithology variation, therefore the same lithology was given to all the layers (sandstone).

- Model e tests the influence of the weakest calibration values, which are the BHTx_AAPG. We therefore removed them and the model has been calibrated using only the DST and BHTx_ICS values.

- Model f, also called the 'preferred' model, is the model with the best results (see section 5 for details).

For a better comparison of the six models, the scales have been normalised such that the minimum and maximum temperature is the same for all models at a given depth. The first comparison

Table 2. Parameters for the lower layers of the model.

\begin{tabular}{lll}
\hline Parameter name & Unit & Value \\
\hline Lithosphere Thickness & $\mathrm{m}$ & $10^{5}$ \\
Crust Thickness & $\mathrm{m}$ & $3.4 \times 10^{4}$ \\
Crust density & $\mathrm{kg} / \mathrm{m}^{3}$ & 2900 \\
Mantle Density & $\mathrm{kg} / \mathrm{m}^{3}$ & 3400 \\
Crust conductivity & - & 2.6 \\
Mantle conductivity & - & 3 \\
Upper Crust Heat production $(0$ means $40 \%)$ & $\mu \mathrm{W} / \mathrm{m}^{3}$ & 0 \\
Lower Crust Heat production & $\mu \mathrm{W} / \mathrm{m}^{3}$ & 0.5 \\
Lithosphere thermal expansion & - & $3.2 \times 10^{-5}$ \\
Lithosphere base temperature & ${ }^{\circ} \mathrm{C}$ & 1330 \\
\hline
\end{tabular}


point between the different models is the result, for each iteration, of the average misfit between the calibration data and the model. For each iteration and for each model, Figure 10 represents the misfit between the calibration data and the result from the model at the exact same location. The model that gives the highest smoothing for the heat production of the upper crust (model b) shows the worst results, and even gives an increase in the misfit between the third and the fourth iteration. The model with a single lithology for all the sediments (model d) also produces bad results. The four other models show a similar misfit evolution, but the final result remains the best for both the reference model (model a) and the best model (model f).

The models will be referred to using their row letter. The reference model (model a in Fig. 8) is equivalent to the 'best' temperature model listed as model f. However, for the sake of clarity it excludes the thickness differentiation of the PreSilesian and Silesian, replacing this with a single Carboniferous unit that is composed of shale and has a thickness of $2500 \mathrm{~m}$. The variable parameters for the iterations in the reference model $\mathrm{a}$ and 'best' model $\mathrm{f}$ give the best results with the following input values:

- for the initial lithosphere thickness: a low variation between

0.8 and 1.2 times the value and a smoothing radius of $100 \mathrm{~km}$ for the thickness;

- for the heat production of the upper crust: a variation between 0.1 and 3 times the value with a smoothing radius of $10 \mathrm{~km}$.

The two first comparison models deal with the amplitude of variations of the parameters that are used to decrease the misfit between the model and the calibration data. Model b (row ' $\mathrm{b}$ ' on Fig. 8) tests the reactivity of an increased smoothing radius (50 km instead of $10 \mathrm{~km}$ ) for the heat production in the upper crust. Model c (row ' $c$ ' on Fig. 8) allows the lithosphere thickness to vary between 0.6 and 1.4 (instead of 0.8 and 1.2) and decrease the smoothing to $25 \mathrm{~km}$ (instead of $100 \mathrm{~km}$ ). Model d (row ' $\mathrm{d}$ ' on Fig. 8) presents all the sediments with the same lithology
(100\% sandstone); the objective of this model is to test the influence of a variation in lithology (which implicitly means a variation in thermal conductivity for the thermal model) in the basin. In model e (row 'e' on Fig. 8), the calibration dataset is only composed with the DST and BHTx_ICS.

In model c, despite the higher variations of the lithosphere thickness and the lower smoothing radius (Fig. $8 \mathrm{c} 9$ ), the temperature results are very close to the reference model. In this model, the upper crust heat production (Fig. 8 c8) compensates for the lithosphere thickness. In model $b$, the upper crust heat production smoothing radius is increased (Fig. 8 b8) but the lithosphere thickness (Fig. 8 b9) cannot compensate. The temperature, resulting from this smoother heat production radius, is higher than average and has very large scale variations. In the reference model, the horizontal variation of the temperature between a high and low value is equivalent to the variations observed in the upper crust heat production (Figs. 9 a8). By increasing the smoothing radius in the upper crust heat production, the model cannot correctly fit the data (Fig. 10). The temperature results therefore become unrealistic (Fig. 8b).

The lithology assigned to the stratigraphic units also has a very high impact on the final temperature results. The first evidence for this is a misfit between the model without variation in lithology, and other models (Fig. 10). The temperature from model d (Fig. 8d) shows low variations and a low average temperature, despite the high heat flow (Fig. $8 \mathrm{~d} 7$ ) that results from upper crust heat production (Fig. $8 \mathrm{~d} 8$ ), and the small thickness of the lithosphere (Fig. $8 \mathrm{~d} 9$ ). The source of the low temperature can be explained by a lack of low conductive lithology (shale) in the sediments. With regard to models e and $\mathrm{f}$, the temperature results are very close to the reference model, as expected given the very similar upper crust heat production (Fig. 8 e8 and f8) and lithosphere thickness (Fig. 8 e 8 and f8) results. In model e, the temperatures (Fig. 8 e1 to e6) show less or even no variation (e.g., south-east of the Dutch territory) in relation to the lack of the BHTx_AAPG values (see Fig. 5). The temperature results (Fig. 8 e) are similar to the reference model (Fig. 8 a) for those areas with a high concentration of BHT

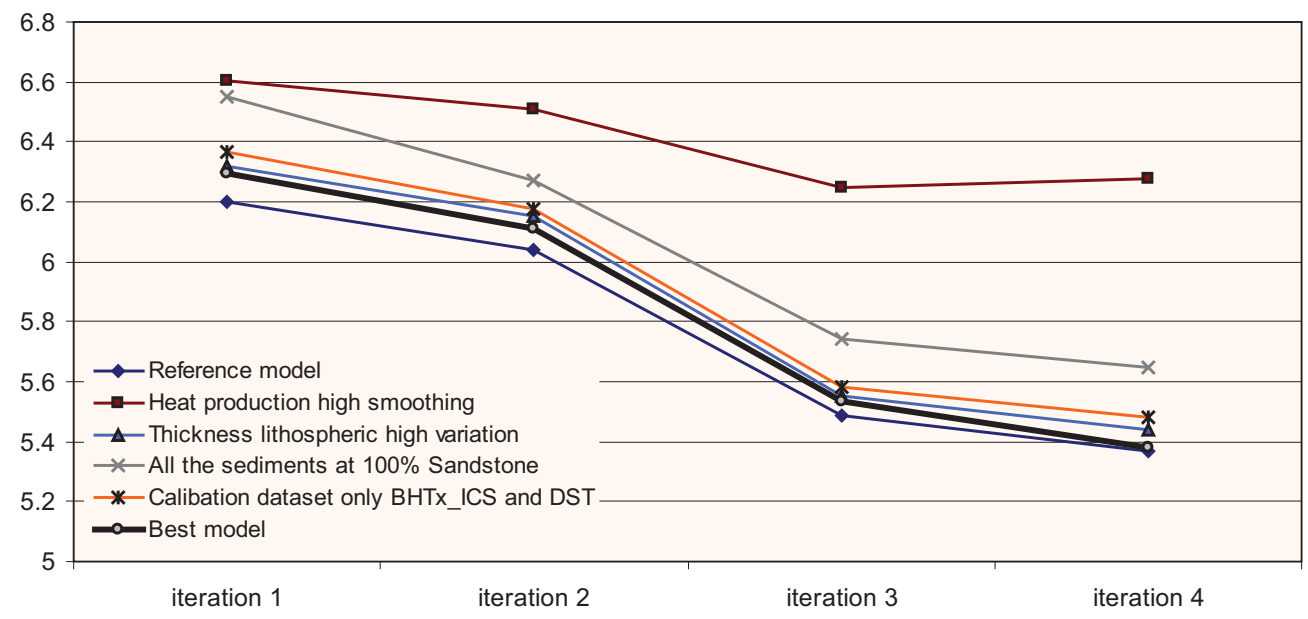

Fig. 10. Evolution of the misfit value for each model (see text and Fig. 9 for details) and for each iteration. 
values (e.g., the north of the Friesland Platform) but the areas that have a low concentration or that rely only on the BHTx_AAPG show important differences (e.g., in the eastern part of the West Netherlands Basin). For the 'best' model $f$, the difference from the reference model $a$ is most apparent in relation to the deepest temperatures. With respect to the reference model, the heat flow variations are specifically important in the Roer Valley Graben and in the West Netherlands Basin (Fig. 8 f7). At $4000 \mathrm{~m}$ (Fig. $8 \mathrm{f} 4$ ) and below (Fig. $8 \mathrm{f} 5$ and f6), differences from the reference model become even more apparent. At $6000 \mathrm{~m}$ (Fig. $8 \mathrm{f} 6$ ), the major differences are the very high temperatures in the western part of the Central Netherlands Basin and the very low ones in the London-Brabant Massif.

\section{Preferred model}

The model temperature of the preferred model $\mathrm{f}$ is presented through maps for every $1000 \mathrm{~m}$ in depth, from $1000 \mathrm{~m}$ to $6000 \mathrm{~m}$ (Fig. $8 \mathrm{f1-f6),} \mathrm{showing} \mathrm{that} \mathrm{major} \mathrm{trends} \mathrm{of} \mathrm{above-} \mathrm{and} \mathrm{below}$ average temperatures occur at different depths. For example, the West Netherlands Basin and the Roer Valley Graben show an important low temperature trend at shallow depths, but at greater depths temperatures are above average. In some areas, high or low temperature zones are present at every depth, although their lateral extent may vary. This can be seen, for instance, in the northern part of the Friesland Platform and the Texel-IJsselmeer High.

\section{Validity of the model in comparison to calibration values}

For comparing the temperature between model predictions and measurements, we used two complementary approaches. The first of these analyses the modelled and observed temperature depth trends in particular wells, while the second analyses deviations of the modelled and observed temperatures at particular depth levels.

\section{$1 D$ validation on a selection of wells}

To compare the modelled temperatures from the best model with observations in wells, we selected ten wells (Fig. 11) representative of the different structural elements of the Dutch territory. The wells have been chosen based on two main criteria: firstly, the wells need to include a reasonable number of data (at least 4 values), and secondly, the proportion of BHTx_ICS and DST (if available) values should be as high as possible. The well that is referred to here by the name ANJ-xx refers to the collective temperature values of wells ANJ-01, ANJ-02, ANJ-03 and ANJ-04, which are found in extremely close proximity (less than $500 \mathrm{~m}$ ). As the modelling method takes into account not only the well itself but also the closest values around the well in order to calibrate the model, we also selected those wells in a radius of $10 \mathrm{~km}$ around each initial well. The result of the comparisons between the model and the values within the $10 \mathrm{~km}$ radius are given in Fig. 12. The first observation is that the results show a good fit with the calibration data, with the exception of one value in well BNV-01 at a depth of $1789 \mathrm{~m}$. The two BHT values used for the ICS correction at $1789 \mathrm{~m}$ in well BNV-01 show a similar value of $42^{\circ} \mathrm{C}$ for different 'shut-in-time' values implying that the reliability of these values should be reconsidered. The second major misfit concerns calibration temperatures from depths greater than $4000 \mathrm{~m}$ in well LTG-01, which are all higher than those modelled. In LTG-01 well, the Carboniferous is reached at $1776 \mathrm{~m}$ (shale lithology with coal interbeds of Westphalian age), and the Devonian (very low porosity limestone) is attained around $3800 \mathrm{~m}$. The heat flow from the model at the base of the basin fill gives a value of $56 \mathrm{~mW} / \mathrm{m}^{2}$, which is comparable to the surrounding values of $\leqslant 53 \mathrm{~mW} / \mathrm{m}^{2}$. This value is too low to be able to reach the high temperatures required by using coherent thermal conductivity values in the Carboniferous (around 1.7) and in the Devonian (between 2 and 3). Ziegler (1990) suggested that this area experienced a magmatic intrusion during the collapse of the Variscan orogen (Ziegler, 1990) that is capable of generating radiogenic heat ranging from 2 to $3 \mu \mathrm{W} / \mathrm{m}^{3}$ (Jolivet et al., 1989). This additional heat production could increase the basement heat flow from 56 to $70 \mathrm{~mW} / \mathrm{m}^{2}$, which better explains the deeper temperature values measured in the well.

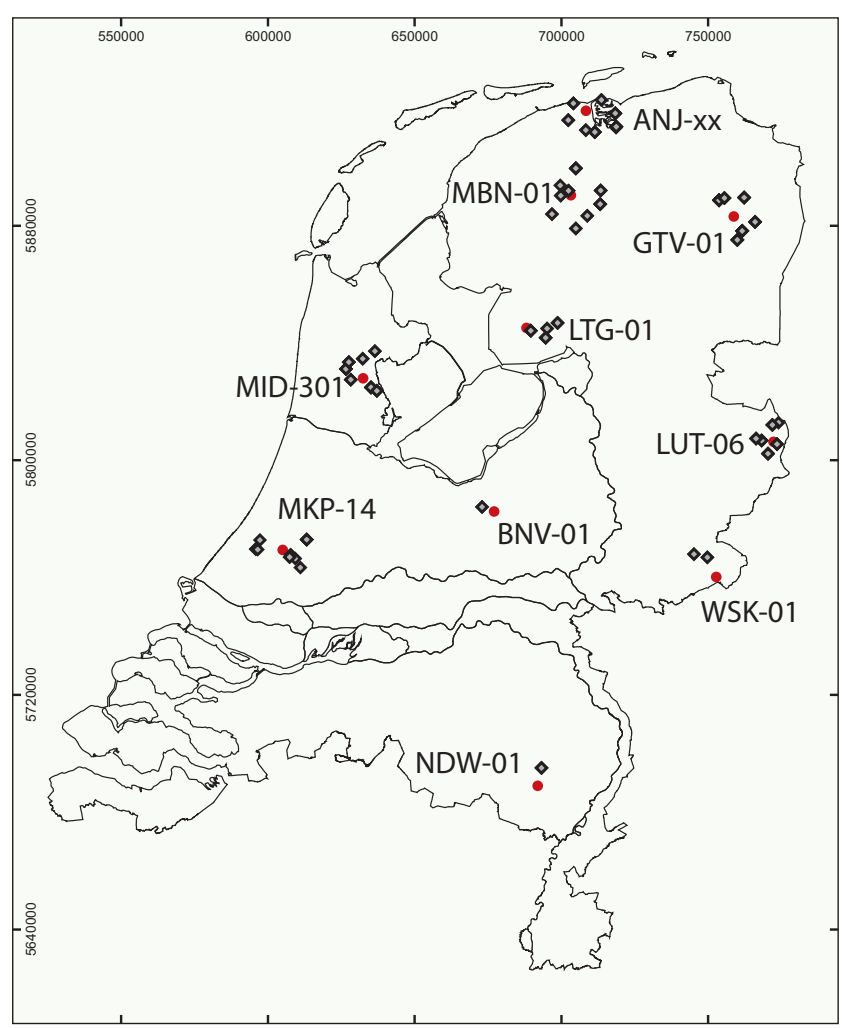

Fig. 11. Localities of the wells selected to show the comparison between the result of the model (best model) and the calibration values. Red dots: wells represented and compared to the model result. Diamond: values of wells found within a diameter of $10 \mathrm{~km}$ of the main well. 

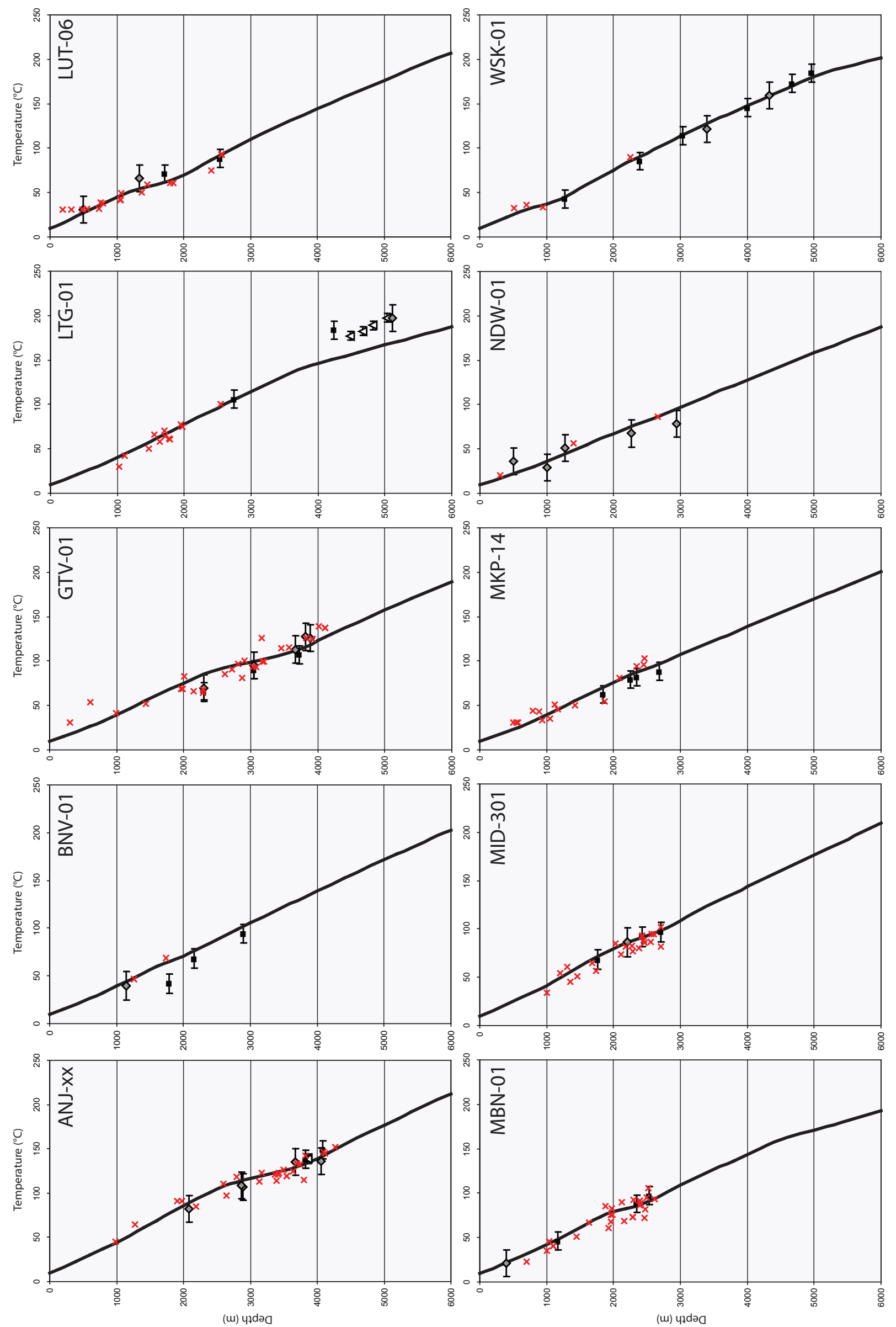

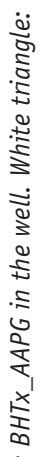

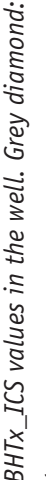

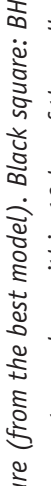

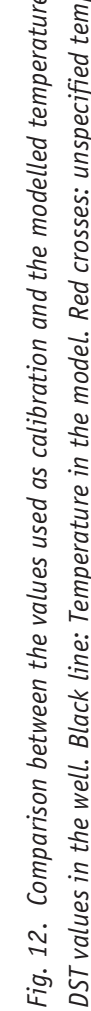


For all other wells (Fig. 11) it appears that the variation in thermal conductivity in relation to the change of lithology is an important source of variation in the modelled temperature. The presence of Zechstein salt in the northern part of the country (Geluk, 2007) has clearly influenced the trends from wells ANJ-xx, GTV-01, MBN-01, LUT-06, and MID-301. The high conductivity values for salt (greater than 4 ) will generate a lower thermal gradient at an equivalent heat flow. This low thermal gradient is visible as a vertical trend; e.g., between $2700 \mathrm{~m}$ and $3700 \mathrm{~m}$ in well ANJ-xx, between $2200 \mathrm{~m}$ and $3600 \mathrm{~m}$ in well GTV-01, and between $1200 \mathrm{~m}$ and $2000 \mathrm{~m}$ in well LUT-06. In contrast to this, layers with a high proportion of shale have a low conductivity (below 2), which increases the thermal gradient. In those cases where the shale is associated with coal (thermal conductivity between 0.9 and $1.5 \mathrm{~W} /(\mathrm{m} \cdot \mathrm{K})$ ) the gradient is further increased. The Carboniferous has a significant proportion of coal in its upper layer, which is shown by the steep gradients in wells LTG-01 (between $1700 \mathrm{~m}$ and $3700 \mathrm{~m}$ ), MBN-01 (between $2550 \mathrm{~m}$ and $4500 \mathrm{~m}$ ), and WSK-01 (between $1700 \mathrm{~m}$ and $5700 \mathrm{~m}$ ).

\section{Modelled temperature vs observed temperatures at various} depths

To evaluate misfits between the model- and calibration data in map view, isodepth maps of the residual temperature were generated for every $1000 \mathrm{~m}$ between 1000-5000 m (Fig. 13). These residual temperature maps are an interpolation at a specific depth between the modelled temperature and the temperature values used as calibration. Positive values indicate that the modelled temperatures are higher than the observed values; negative values indicate the opposite. The interpolation has been performed through a 3D steady state thermal model with a temperature of $0{ }^{\circ} \mathrm{C}$ at the top, residual temperatures at well points and a heat flow of $0 \mathrm{~mW} / \mathrm{m}^{2}$ on the opposite side of the model.

At $1000 \mathrm{~m}$ (Fig. 13a), some residual values are positive while others within a short distance are negative, which implies that no systematic trends exist. As depth increases, the residual temperatures at $2000 \mathrm{~m}$ (Fig. 13b) and $3000 \mathrm{~m}$ (Fig. 13c) show trends that are also visible in the lowest part of the model (Figs 14d-f) where there are fewer calibrated values (Fig. 5a). In the north of the country, the model tends to underestimate the temperature; this has affected results for the northern part of the Lauwerszee Trough and the area to the southeast of the Lower Saxony Basin (close to the Ems Low). Temperatures at $4000 \mathrm{~m}$ are also underestimated at the eastern extent of the Texel-IJsselmeer High (Fig. 13). The misfit in this area is also visible in $1 \mathrm{D}$ throughout the entire depth range of well LTG-01 (Fig. 12). In contrast, the modelled temperatures for the western half of the West Netherlands Basin are slightly overestimated in comparison to the calibration data.
It is noticeable in Fig. 13 that the negative values (i.e., where the modelled temperatures are lower than the calibration values) have a larger spread and show higher values.

\section{Sources and origins of thermal perturbations}

Changing the parameters for upper crust heat production and lithosphere thickness has a significant impact on the temperature of the model (Fig. 8). Therefore, misfits between modeland the measured temperatures are likely to be produced by local variations of these parameters. However, variations of thermal conductivity related to the change of lithology (Fig. 8d) have the most significant impact on the final temperature result. In the best model, presented in Fig. 10, there are two layers that create remarkable variations in the temperature: these are the Zechstein and the Silesian.

In the Dutch subsurface onshore, the repartition of the various Zechstein lithologies is far from homogenous. This is due to the position of the Netherlands at the southern border of the Southern Permian Basin (SPB) during the deposition of the Zechstein Group (Geluk, 2005). As a result, the southern part of the Dutch territory (south of the present location of the Central Netherlands Basin) mainly comprises Zechstein sandstone and carbonate, while the north has a very high proportion of evaporites. The thickness of the Zechstein Group reflects the northward deepening of the SPB, with the thickness increasing to the north of the Friesland Basin (Fig. 15e). In geological times, periods of salt flow generated salt diapirs, which are visible in Fig. 15. While the thickness of the Zechstein in the Lauwerszee Trough is on average $800 \mathrm{~m}$, some diapirs show a height of over $2500 \mathrm{~m}$. In the Lower Saxony Basin, where a large number of diapirs were fed by surrounding salt, the effect of salt depletion is visible through local salt thicknesses of less than $200 \mathrm{~m}$. On cross-section C-C' (Fig. 14), a 1500 m-high diapir is visible at the junction between the Lauwerszee Trough and the Groningen High. The impact of salt on the subsurface temperature is explained by its high thermal conductivity. Since Van Engen (1975) first approached this issue, the influence of salt structures on the temperature has been discussed by several authors (e.g., Vermooten et al., 2004; Verweij, 2003). For the southern, sandy part of the Zechstein basin, a thermal conductivity of $2 \mathrm{~W} /(\mathrm{m} \cdot \mathrm{K})$ has been used, progressively increasing to the north to reach 3.9. The evaporites have a strong visible impact on the northern part of the Friesland Platform (i.e., in the Lauwerszee Trough, Groningen High, and Lower Saxony Basin), where the thickness of the Zechstein layer has been modified to generate diapirs. The base of the Zechstein layer is just below $3000 \mathrm{~m}$ in the central part of the Lauwerszee Trough (Fig. 15d) and it becomes deeper towards the German border, reaching a depth of $4300 \mathrm{~m}$ in the Lower Saxony Basin. However, due to the presence of structured salt the thickness of the Zechstein shows important variations (Fig. 15b). In the central part of the Lauwerszee Trough, the Zechstein base lies at a 

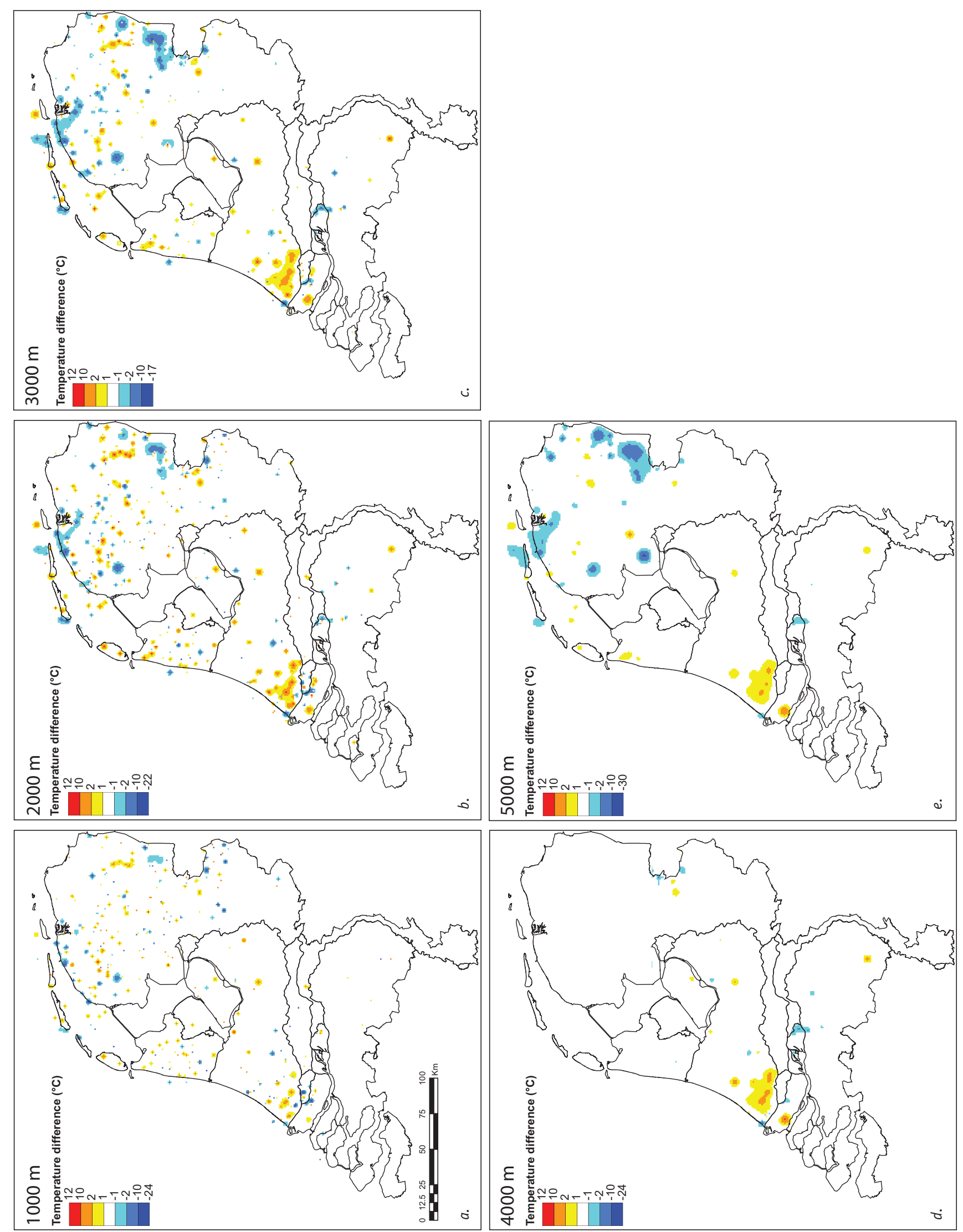

Fig. 13. Isodepth maps of the temperature difference between the model and the temperature calibration data. Positive/negative values indicate that the modelled temperatures are higher/lower than the calibration temperatures. See text for details. 
rather uniform depth and thickness of $\sim 2300 \mathrm{~m}$ and $\sim 800 \mathrm{~m}$ respectively (Fig. 15b). Along its borders, i.e., at the junction of the Lauwerszee Trough and the Groningen High, and at the Hantum Fault Zone, salt walls occur with thicknesses of between $1000 \mathrm{~m}$ and $1500 \mathrm{~m}$ that are closely related to the faults in the underburden of the Zechstein (Fig. 14; cross-section C-C').The temperature is strongly influenced by these salt walls. At the top of the Zechstein, the temperature maps (Fig. 15c) show large variations that are intrinsically related to the depth variations of the layer, while at its base (Fig. 15a), the temperature variation

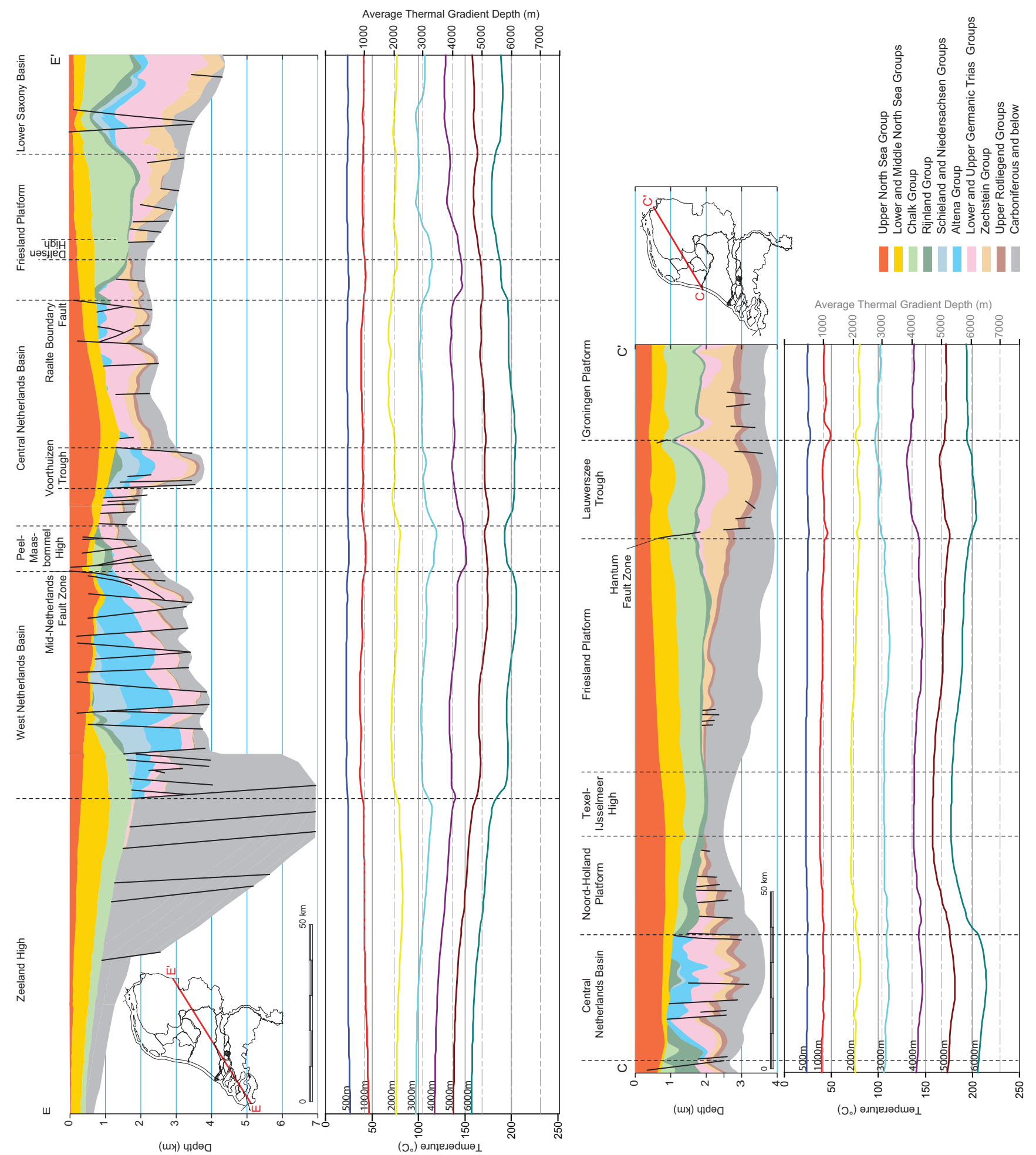

Fig. 14. Cross-sections correlating the main geological layers and the temperature from the 'best model' at seven different depths (Source for the geological cross-sections: TNO-NITG, 2004). In the temperature profiles, the coloured lines show the temperature at a given depth, the grey plain lines give the temperature every $50^{\circ} \mathrm{C}$, and the grey dashed line gives the temperature every $1000 \mathrm{~m}$ using the average geothermal gradient defined in text $(T=0.0313 \cdot z+10.086)$. 

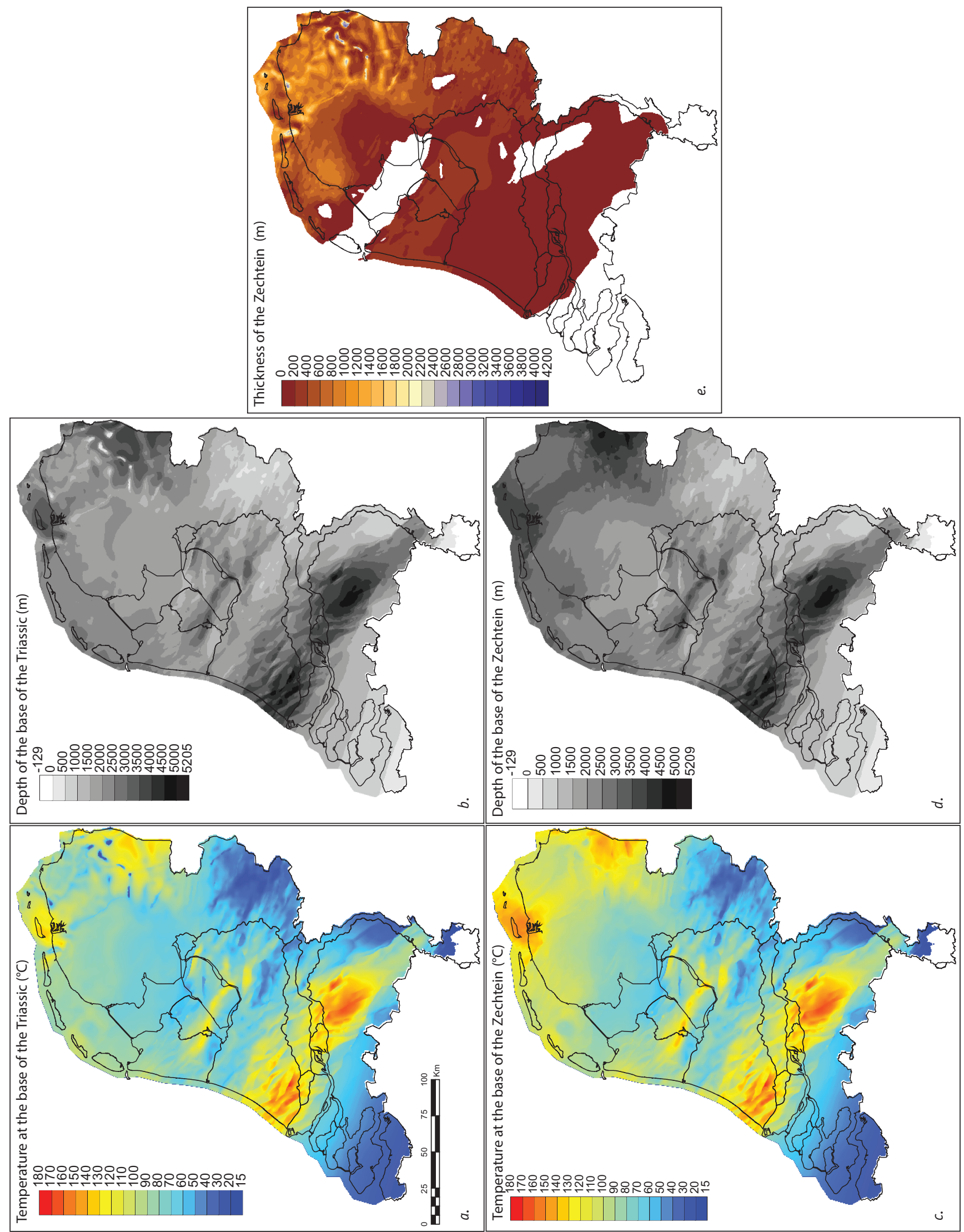

Fig. 15. Temperature at the top and the base of the Zechstein Group in relation to the depth and thickness of layers. a. Temperature at the base of the Triassic (top Zechstein); b. Depth at the base of the Triassic (top Zechstein); c. Temperature at the base of the Zechstein; d. Depth at the base of the Zechstein; e. Thickness of the Zechstein Group. 

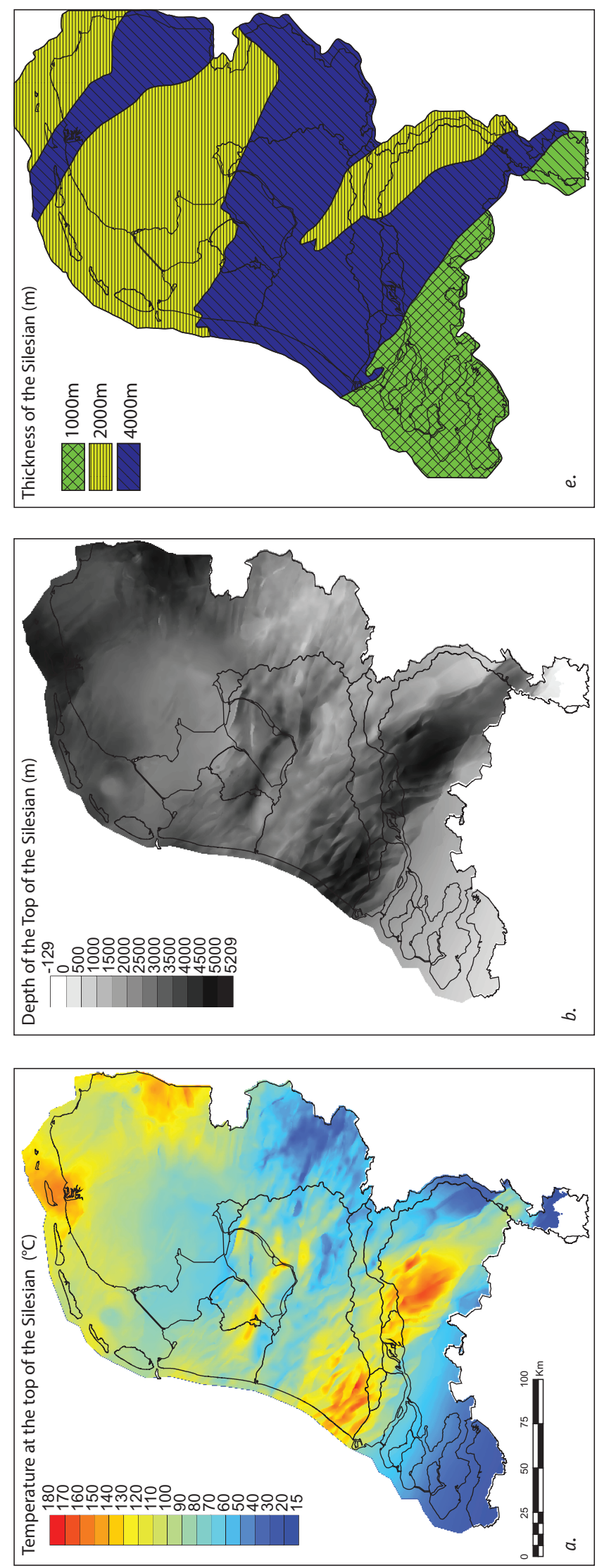

Fig. 16. a. Temperature at the top of the Silesian; b. Depth at the top of the Silesian; c. Thickness of the Silesian. in this particular area is smooth and low. On cross-section C-C' (Fig. 14b), the temperatures at the location of the walls at a depth of $1000 \mathrm{~m}$ are higher than in the central part of the Lauwerszee Trough (up to $48.5^{\circ} \mathrm{C}$ instead of $41^{\circ} \mathrm{C}$ ). Further down (at $2000 \mathrm{~m}$ ), the temperature at the wall location is lower than in the trough $\left(75^{\circ} \mathrm{C}\right.$, compared to $79^{\circ} \mathrm{C}$ on the north wall) but remains low in its extension. At $3000 \mathrm{~m}$, the extension of this effect has increased on the northern wall, leading to a temperature difference of $5^{\circ} \mathrm{C}$. In the Lower Saxony Basin, the amplitude of the salt diapirs is larger than in the Lauwerszee Trough, with thicknesses between $2000 \mathrm{~m}$ and $3000 \mathrm{~m}$ (Fig. 15e) with some diapir tops less than $500 \mathrm{~m}$ from the surface (Fig. 15b). The temperature impact of these structures is reflected in the high temperatures above the diapirs (Fig. $8 \mathrm{f} 1$ ). Below the diapiric structures, the temperature decreases from depths of $2000 \mathrm{~m}$ (Fig. $8 \mathrm{f} 2$ ) or $3000 \mathrm{~m}$ (Fig. $8 \mathrm{f} 3$ ), depending on the depth of the base of the Zechstein (Fig. 15d). Below $3000 \mathrm{~m}$, the effect is still visible but it disappears progressively with depth.

In the north of the Netherlands, the presence of Silesian (Carboniferous) rocks also has a major impact on the temperature (Visser, 1978). Whereas the impact of the Zechstein salt is limited to the north, the Silesian is present throughout the entire Dutch territory. The main variations within the Silesian are related to the lithological differences associated with depositional setting within the basin. Here, we have considered the Silesian to be a single layer and we have used an average lithology that takes into account the high proportion of shale and noticeable amount of coal (locally up to 2.1\%). The presence of this insulating layer results in lower temperatures at the top of the Silesian and higher-than-average values at the base. As the thickness and depth of the Silesian varies from one geological province to another (Fig. 16), these temperature variations appear at different depths.

In the Northern Dutch onshore, the top of the Silesian is relatively shallow at the Texel-IJsselmeer High, the south of the Friesland Platform and the Noord Holland Platform (Figs 14 and 16b). This shallow depth is caused by several phases of uplift and erosion, which also explains the almost complete absence of Mesozoic (with the exception of some Chalk) and Permian rocks. In comparison to the average temperature of the geothermal gradient in the Netherlands, the temperature at $1000 \mathrm{~m}$ and $2000 \mathrm{~m}$ (above the Silesian) is lower by a few degrees where the top of the Silesian is at its shallowest. In the surrounding area, and at an equivalent depth, the temperature increases as it diverges from this centre (Fig. 14) in relation to the deepening of the top of the Silesian. In the lower part of the Silesian (i.e., at $3000 \mathrm{~m}$ ) and just below this (i.e., $4000 \mathrm{~m}$ ) the temperature is higher than for the average gradient, even if the central Texel-IJsselmeer High still remains the coldest section of the whole area (Figs 8 and 14). The basement depth below the Texel-IJsselmeer area is at about $5000 \mathrm{~m}$, and because of its relatively high conductivity, temperature gradients here remain very low, and certainly below the expected temperature 
calculated from the Dutch average thermal gradient. This is clearly noticeable on the $6000 \mathrm{~m}$ temperature map (Fig. $8 \mathrm{f} 6$ ), where low temperature values appear as an alignment that runs southeast-northwest (parallel to the Texel-IJsselmeer High) and is only disturbed by the slightly hotter magmatic intrusion zone that surrounds well LTG-01 (see Fig. 11 for location).

On the Friesland Platform, in the north of the Netherlands (profile E-E', Fig. 14), the temperature-depth trend is similar to that of the area around the Texel-IJsselmeer High (i.e., slightly lower temperatures above, and higher temperatures below, the Silesian unit). Local differences are related to thickness variation of the Silesian that causes a specific thermal pattern. The major difference is that the top of the Silesian juts out towards the north, causing an increase in depth of the top Silesian of $1000 \mathrm{~m}$ within some $25 \mathrm{~km}$. This area of shallow Silesian has a $2000 \mathrm{~m}$ thick Silesian surrounded by sections with a Silesian that is $4000 \mathrm{~m}$ thick (i.e., the Central Netherlands Basin and the Lower Saxony Basin). As a result of these thickness differences, it is plausible that the heat trapped below the low conductive Silesian is diverted from the north of the Friesland Platform to the south. The result of this effect is visible on temperature profile E-E' (Fig. 14), where the southern part of the Friesland Platform below $3000 \mathrm{~m}$ has a higher temperature than the northern part. Alternatively, these variations can be related to differences in thermal conductivities. Also noticeable on both cross-section E-E' (Fig. 14) and temperature maps (Fig. 8), is that the temperatures at $3000 \mathrm{~m}$ and $4000 \mathrm{~m}$ show values that are higher than average, while at $5000 \mathrm{~m}$ and below, they progressively became lower than average.

In the central part of the country, the Maasbommel High and the Peel Block also have a Silesian thickness of $2000 \mathrm{~m}$ and show very high temperatures from $3000 \mathrm{~m}$ in depth to $5000 \mathrm{~m}$ in depth. Just as with the south-east part of the Friesland Platform discussed earlier, this area is surrounded by a $4000 \mathrm{~m}$-thick Silesian layer (Figs 16c and 14). The sink effect may also occur here, since the Maasbommel High becomes a zone of preferential heat transfer from the north of the West Netherlands Basin and the south of Central Netherlands Basin. In the south of the country, where the thickness of the Silesian is only $1000 \mathrm{~m}$ (Fig. 16c), the temperature is transferred from the south of the West Netherlands Basin to the Zeeland Platform. Again, differences in thermal conductivity may explain these variations in temperature as well. The effect is visible on the temperature map at $3000 \mathrm{~m}$ (Fig. 10), but also appears on profile E-E' at the junction between the West Netherlands Basin and the Zeeland Platform at $2000 \mathrm{~m}$ and $3000 \mathrm{~m}$.

Similar patterns can be identified between areas with a Silesian thickness of $2000 \mathrm{~m}$ and areas with a thickness of $4000 \mathrm{~m}$. In all of these deep basins, the Silesian is thicker and the top of the Silesian is deeper than the surrounding high. The temperature profiles on Fig. 14 show similar trends in the West Netherlands Basin (profile E-E'), the Central Netherlands Basin (profile E-E' and C-C'), and the Lauwerszee Trough (profile
C-C'). In all these basins, the temperature is very close to the reference values from the average geothermal gradient. However, the temperature tends to be a few degrees lower at the top and above the Silesian, while it is few degrees higher at the bottom or below. The high temperatures of these basins are visible on the temperature map of the top of the Silesian (Fig. 16a).

In the south of the Netherlands, the Roer Valley Graben shows a low temperature at shallow subsurface (Fig. 8), which can be related to fluid flow (Luijendijk et al., 2011).

\section{Improvements compared to previous works}

The aim of this study is to provide a better, more comprehensible and higher reliability dataset of subsurface temperatures. In our approach, we assessed the reliability of various temperature data sets by comparing them to undisturbed formation temperatures. The first dataset is composed of 412 BHTx_ICS and 52 DST; these temperatures can be considered representative for the temperature of the considered formation. These temperatures have been completed by 829 BHTx_AAPG values to increase the density of calibration points. As one of our targets was to obtain subsurface temperature for the entire Dutch territory, we used 829 BHTx_AAPG measurements that were suitable for this purpose. The temperature maps generated with this dataset can be compared with previous results provided in these atlases (Table 3). The temperature maps generated in this study (Fig. 8) corroborate earlier studies (e.g., Rijkers \& Van Doorn, 1997; Van Doorn \& Rijkers, 2002). However, whereas in previous atlases the precision of the maps was related entirely to the dataset that was available for each given depth, the modelling used in this study takes into account the lithology through the variations of thermal conductivity in the different layers of the model. As a result, in this study, the contours of the anomalies have improved due to the control of the lithology and the areas with a low control of the temperature values are better constrained than with an interpolation-based approach.

\section{Conclusion}

The first purpose of this work was to present a coherent subsurface temperature dataset. To achieve this, we used a prebuilt BHT dataset that includes the 'shut-in-time', the TVD (True Vertical Depth) of the measurements and the BHT measurements. An ICS correction method was applied to this dataset, followed by an AAPG method in order to increase the number of reliable values. Our second purpose was to get a better understanding of the obtained subsurface temperatures in the Netherlands. To this end, we used this dataset to calibrate various 3D temperature models of the whole Dutch subsurface. The specific nature of this method enabled us to use the complete lithosphere evolution of the last $20 \mathrm{Myr}$ in order to provide a transient temperature result. As with any modelling method, the physics involved in the process was given a primary 
Table 3. Comparison of the minimum and maximum temperatures visible on the isodepth maps presented in this paper and those of previous studies.

\begin{tabular}{|c|c|c|c|c|c|c|c|c|c|c|c|c|c|c|c|c|}
\hline \multirow{3}{*}{$\begin{array}{l}\text { Dutch data provider } \\
\text { for the Netherlands }\end{array}$} & \multirow[t]{3}{*}{ Atlas reference } & & \multicolumn{14}{|c|}{ Temperature ${ }^{\circ} \mathrm{C}$} \\
\hline & & & \multicolumn{2}{|c|}{$500 \mathrm{~m}$} & \multicolumn{2}{|c|}{$1000 \mathrm{~m}$} & \multicolumn{2}{|c|}{$1500 \mathrm{~m}$} & \multicolumn{2}{|c|}{$2000 \mathrm{~m}$} & \multicolumn{2}{|c|}{$2500 \mathrm{~m}$} & \multicolumn{2}{|c|}{$3000 \mathrm{~m}$} & \multicolumn{2}{|c|}{$5000 \mathrm{~m}$} \\
\hline & & & Min. & Max. & Min. & Max. & Min. & Max. & Min. & Max. & Min. & $\operatorname{Max}$. & Min. & Max. & Min. & Max. \\
\hline \multirow[t]{2}{*}{ Prins, 1980} & Haenel et al., & NL scale & - & - & $<40$ & $>55$ & - & - & - & - & - & - & - & - & - & - \\
\hline & 1980 & European scale & $<25$ & $>30$ & $<40$ & $>50$ & $<55$ & $>70$ & $<70$ & $>90$ & $<85$ & $>105$ & $<100$ & $>120$ & $>160$ & $>180$ \\
\hline Lokhorst \& Van & Haenel \& Staroste, & NL scale & $<20$ & $>30$ & - & - & - & - & - & - & - & - & - & - & - & - \\
\hline Montfrans, 1988 & 1988 & European scale & - & - & $<45$ & $>50$ & - & - & $<75$ & $>90$ & - & - & - & - & - & - \\
\hline Ramaekers, 1992 & Hurtig et al., 1992 & European scale & $<20$ & $>25$ & $<40$ & $>50$ & - & - & $<70$ & $>90$ & - & - & $<100$ & $>120$ & $>160$ & $>180$ \\
\hline Rijkers \& Van Doorn, 1997 & & NL scale & $<20$ & $>30$ & $<40$ & $>55$ & - & - & $<65$ & $>95$ & - & - & $<85$ & $>130$ & - & - \\
\hline \multirow[t]{2}{*}{ Van Doorn \& Rijkers, 2002} & Hurter \& Haenel, & NL scale & $<20$ & $>30$ & - & - & - & - & - & - & - & - & - & - & - & - \\
\hline & 2002 & European scale & - & - & 40 & 60 & - & - & 60 & 100 & - & - & - & - & - & - \\
\hline TNO-NITG, 2004 & TNO-NITG, 2004 & NL scale & - & - & - & - & - & - & $<70$ & $>90$ & - & - & - & - & - & - \\
\hline This study & & NL scale & - & - & 30 & 56 & - & - & 62 & 92 & - & - & 84 & 130 & 136 & 186 \\
\hline
\end{tabular}

definition. The model used for this paper describes the evolution of the temperature using a purely conductive methodology: the different layers engender variations of the temperature in the model through heat production and variations in thermal conductivity. The definition of some parameters was discussed in some detail in order to confirm the choices made for each value, with the key parameters being as follows: the layer composition and geometry, the number of calibration data, the smoothing radius of the lithosphere, and the smoothing radius of the upper crust radiogenic heat production.

Analysis of the temperature anomalies shows variations in the temperature in relation to two major layers, the Zechstein (i.e., high thermal conductivity) and the Carboniferous (i.e., low thermal conductivity). For example, at the south of the Groningen High, the Zechstein layer generates higher temperatures at a depth of $1000 \mathrm{~m}$ and lower temperatures at a depth of $2000 \mathrm{~m}$ depth, which is a typical response to a salt-composed layer. This impact is also visible in well GTV-01, which shows a very low thermal gradient between $2 \mathrm{~km}$ and $4 \mathrm{~km}$. In contrast to this, the impact of the Carboniferous layer has a warming effect deeper down and a cooling effect higher up (usually not visible due to the depth and thickness of the Carboniferous). The warming effect below the Carboniferous is observable at $4000 \mathrm{~m}$ in the Maasbommel High.

For exploring geothermal energy in sedimentary basins, subsurface temperature is one of the key parameters that must be taken into account, together with the location of the potential geothermal reservoirs (e.g., depth, extension, and so on) and their petrophysical parameters (see Pluymaekers et al., this issue). The temperature model of the Netherlands presented here has been incorporated in the ThermoGIS project, visible online at www.thermogis.nl.

\section{Acknowledgements}

This study was supported by TN0 and Utrecht University. We thank M. Scheck-Wenderoth and M. ter Voorde for their constructive reviews. Thanks to J. ten Veen for both his very useful contribution and his patience. A grateful thanks to the wonderful Rosie Bonté for editing the text and correcting the English.

\section{References}

Artemieva, I.M., Thybo, H. \& Kaban, M.K., 2006. Deep Europe today: Geophysical synthesis of the upper mantle structure and lithospheric processes over 3.5 By. In: Gee, D.G. \& Stephenson, R.A. (eds): European Lithosphere Dynamics. Geological Society Memoir (London): 14-41.

Axelsson, G. \& Gunnlaugsson, E., 2000. Geothermal utilisation, management and monitoring. In: Long-term monitoring of high- and low enthalpy fields under exploitation. WGC 2000 Short Courses, Japan: 3-10.

Benderitter, Y. \& Cormy, G., 1990. Possible approach to geothermal research and relative costs. In: Dickson, M.H. \& Fanelli, M. (eds): Small Geothermal Resources: A Guide to Development and Utilization. UNITAR (New York): 59-69.

Blackwell, D.D. \& Richards, M., 2004. Calibration of the AAPG Geothermal Survey of North America BHT Data Base. AAPG Annual Meeting, paper 87616 (Dallas, Texas).

Bonté, D., Guillou-Frottier, L., Garibaldi, C., Bourgine, B., Lopez, S., Bouchot, V. \& Lucazeau, F., 2010. Subsurface temperature maps in French sedimentary basins: new data compilation and interpolation. Bulletin de la Société Géologique de France 181: 377-390.

Boxem, T.A.P., 2010. Steady state 1D temperature modeling of the onshore Dutch subsurface. Netherlands Institute of Applied Science TNO - National Geological Survey (Utrecht), 86 pp. Report number TN0-034-UT-2010-01686.

Brigaud, F., 1989. Conductivité thermique et champ de température dans les bassins sédimentaires à partir des données de puits. $\mathrm{PhD}$ thesis, Université Montpellier, 414 pp. 
Cloetingh, S., Van Wees, J.D., Ziegler, P.A., Lenkey, L., Beekman, F., Tesauro, M., Förster, A., Norden, B., Kaban, M., Hardebol, N., Bonté, D., Genter, A., Guillou-Frottier, L., Ter Voorde, M., Sokoutis, D., Willingshofer, E., Cornu, T. \& Worum, G., 2010. Lithosphere tectonics and thermo-mechanical properties: an integrated modelling approach for Enhanced Geothermal Systems exploration in Europe. Earth Science Reviews 102: 159-206.

De Jager, J., 2007. Geological development. In: Wong, T.E., Batjes, D.A.J. \& De Jager, J. (eds): Geology of the Netherlands. Royal Netherlands Academy of Arts and Sciences (KNAW) (Amsterdam): 5-26.

Deming, D., 1989. Application of bottom-hole temperature corrections in geothermal studies. Geothermics 18: 775-786.

Donders, T.H., Weijers, J.W.H., Munsterman, D.K., Kloosterboer-van Hoeve, M.L., Buckles, L.K., Pancost, R.D., Schouten, S., Sinninghe Damste, J.S. \& Brinkhuis, H., 2009. Strong climate coupling of terrestrial and marine environments in the Miocene of northwest Europe. Earth and Planetary Science Letters 281: 215-225.

Garibaldi, C., 2010. Détermination des températures profondes du Bassin du SudEst de la France et relations entre anomalies thermiques, géologie et circulations hydrothermales par modélisation 3D. PhD thesis, Université de Nice SophiaAntipolis, $284 \mathrm{pp}$.

Garibaldi, C., Guillou-Frottier, L., Lardeaux, J.-M., Bonté, D., Lopez, S., Bourgine, B. \& Bouchot, V., 2010. Relationship between thermal anomalies, geological structures and fluid flow: new evidences in application to the Provence basin (south-east France). Bulletin de la Société Géologique de France 181: 363-376.

Geluk, M.C., 2005. Stratigraphy and tectonics of Permo-Triassic basins in the Netherlands and surrounding areas. PhD thesis, Utrecht University (Utrecht), $171 \mathrm{pp}$.

Geluk, M.C., 2007. Permian. In: Wong, T.E., Batjes, D.A.J. \& De Jager, J. (eds): Geology of the Netherlands. Royal Netherlands Academy of Arts and Sciences (KNAW) (Amsterdam): 63-84.

Goutorbe, B., Lucazeau, F. \& Bonneville A., 2007. Comparison of several BHT correction methods: a case study on an Australian data set. Geophysical Journal International 170: 913-922.

Haenel, R., Legrand, R., Balling, N., Bram, K., Gable, R., Fanelli, M., Prins, S., Burley, A.J., Edmunds, W., Oxburgh, E., Richardson, S. \& Wheildon, J. (eds), 1980. Atlas of subsurface temperatures in the European Community. Commission of the European Communities, Directorate-General Scientific and Technical Information and Information Management (Hannover), $36 \mathrm{pp}$.

Haenel, R. \& Staroste, E., 1988. Atlas of geothermal resources in the European Community, Austria and Switzerland, (Luxemburg).

Hantschel, T. \& Kauerauf, A.I., 2009. Fundamentals of Basin and Petroleum Systems Modeling. Springer-Verlag (Berlin Heidelberg), 476 pp.

Harrison, W.E., Luza, K.V., Prater, M.L. \& P.K., C., 1983. Geothermal resource assessment of Oklahoma. Oklahoma Geological Survey, Special Publications 83-1, $42 \mathrm{pp}$.

Harting, $P$., 1879. Temperatuurbepalingen in een put van 369 meters diepte te Utrecht. Verslagen en Mededelingen. Koninklijke Nederlandse Academie van Wetenschappen. Afdeling Natuurkunde: 393-409.

Hermanrud, C. \& Shen, P.Y., 1989. Virgin rock temperatures from well-logsaccuracy analysis of some advanced inversion models. Marine and Petroleum Geology 6: 360-363.
Hochstein, M.P., 1990. Classification and assessment of geothermal resources. In: Dickson, M.H. \& Fanelli, M. (eds): Small Geothermal Resources: A Guide to Development and Utilization. UNITAR (New York): 31-57.

Hurter, S. \& Haenel, R., 2002. Atlas of geothermal resources in Europe. Commission of the European Communities (Luxemburg), $92 \mathrm{pp}$.

Hurtig, E., Cermak, V., Haenel, R. \& Zui, V.I., 1992. Geothermal Atlas of Europe. Hermann Haack Verlagsgesellschaft $\mathrm{mbH}$, Geographische-Kartographische Anstalt (Gotha), $156 \mathrm{pp}$.

Jaupart, C. \& J.-C., M., 2007. Heat flow and thermal structure of the lithosphere. In: Schubert, G. (ed.): Treatise on Geophysics 6: 217-252.

Jolivet, J., Bienfait, G., Vigneresse, J.-L. \& Cuney, M., 1989. Heat flow and heat production in Brittany (western France). Tectonophysics 159: 61-72.

Kramers, L., Van Wees, J.-D., Pluymaekers, M.P.D., Kronimus, A. \& Boxem, T., 2012. Direct heat resource assessment and subsurface information systems for geothermal aquifers; the Dutch perspective. Netherlands Journal of Geosciences 91-4: 637-649, this issue.

Kombrink, H., Leever, K.A., Van Wees, J.D., Van Bergen, F., David, P. \& Wong, T.E., 2008. Late Carboniferous foreland basin formation and Early Carboniferous stretching in Northwestern Europe - Inferences from quantitative subsidence analyses in the Netherlands. Basin Research 20: 377-395.

Kombrink, H., Doornenbal, J.C., Duin, E.J.T., Den Dulk, M., Van Gessel, S.F., Ten Veen, J.H. \& Witmans, N., 2012. New insights into the geological structure of the Netherlands; results of a detailed mapping project. Netherlands Journal of Geosciences 91-4: 419-446, this issue.

Lampe, C. \& Person, M., 2002. Advective cooling within sedimentary rift basins application to the Upper Rhine Graben (Germany). Marine and Petroleum Geology 19: 361-375.

Lampe, C., Person, M., Noth, S. \& Ricken, W., 2001. Episodic fluid flow within continental rift basins: some insights from field data and mathematical models of the Rhine Graben. Geofluids 1: 42-52.

Lindal, B., 1973. Industrial and other applications of geothermal energy. In: Geothermal energy: Review of research and development. UNESCO, Paris, LC No. 72-97138: 135-148.

Lokhorst, A. \& Van Montfrans, H.M., 1988. The Netherlands. In: Haenel, R. \& Staroste, E. (eds): Atlas of Geothermal Resources in the European Community, Austria and Switzerland. Commission of the European Communities (Brussels): 43-45.

Lokhorst, A. \& Wong, T.E., 2007. Geothermal Energy. In: Wong, T.E., Batjes, D.A.J. \& De Jager, J. (eds): Geology of the Netherlands. Royal Netherlands Academy of Arts and Sciences (KNAW) (Amsterdam): 341-346.

Luijendijk, E., Ter Voorde, M., Van Balen, R., Verweij, H. \& Simmelink, H., 2011. Thermal state of the Roer Valley Graben, part of the European Cenozoic Rift System. Basin Research 23: 65-82.

Muffler, P. \& Cataldi, R., 1978. Methods for regional assessment of geothermal resources. Geothermics 7: 53-89.

Nicholson, K., 1993. Geothermal Fluids. Springer Verlag (Berlin), 264 pp.

Pharaoh, T.C., Dusar, M., Geluk, M.C., Kockel, F., Krawczyk, C.M., Krzywiec, P., Scheck-Wenderoth, M., Thybo, H., Vejbæk, O.V. \& Van Wees, J.D., 2010. Tectonic Evolution. In: Doornenbal, J.C. \& Stevenson, A.G. (eds): Petroleum Geological Atlas of the Southern Permian Basin Area. EAGE Publications b.v. (Houten): 25-57. 
Pluymaekers, M.P.D., Kramers, L., Van Wees, J.D., Kronimus, A., Nelskamp, S., Boxem, T. \& Bonté, D., 2012. Reservoir characterisation of aquifers for direct heat production: Methodology and screening of the potential reservoirs for the Netherlands. Netherlands Journal of Geosciences 91-4: 621-636, this issue.

Press, W.H., Flannery, B.P., Teukolsky, S.A. \& Vetterling, W.T., 1988. Numerical Recipes in C. Cambridge University Press (Cambridge), 513 pp.

Prins, S., 1980. The Netherlands. In: Haenel, R. (ed.): Atlas of subsurface temperatures in the European Community. Commission of the European communities. Th. Schaefer GmbH (Hannover), 36 pp.

Ramaekers, J.J.F., 1992. The Netherlands. In: Hurtig, E., Cermak, V., Hanel, R. \& Zui, V. (eds): Geothermal Atlas of Europe. Hermann Haack Verlagsgesellschaft $\mathrm{GmbH}$.

Rijkers, R. \& Van Doorn, T.H.M., 1997. Atlas of geothermal resources in the European Community, the Netherlands. Netherlands Institute of Applied Geoscience TNO (Utrecht), Report number Report 97-24-A.

Sadée, C.P.M., 1975. An interpretation of South-Limburg subsurface temperature data. Geologie en Mijnbouw 54: 184-193.

Simmelink, H.J., Underschultz, J.R., Verweij, J.M., Hennig, A., Pagnier, H.J.M. \& Otto, C.J., 2003. A pressure and fluid dynamic study of the Southern North Sea Basin. Journal of Geochemical Exploration 78-79: 187-190.

Simmelink, H.J., Verweij, J.M., Underschultz, J. \& Otto, C., 2008. Overpressure distribution in the offshore Netherlands. Overpressure 2008: Present and Future Challenges - A Research Conference (Durham).

Sleep, N.H., 2005. Evolution of continental lithosphere. Annual Review of Earth and Planetary Sciences 33: 369-393.

Steffensen, R.J. \& Smith, R.C., 1973. The importance of Joule-Thomson heating (or cooling) in temperature log interpretation. Paper 4636, SPE Annual Meeting (Las Vegas).

Tesauro, M., Kaban, M.K. \& Cloetingh, S.A.P.L., 2008. EuCRUST-07: a new reference model for the European crust. Geophysical Research Letters 35: L05313.

TNO-NITG, 2004. Geological Atlas of the Subsurface of the Netherlands - onshore. Netherlands Institute of Applied Geoscience TNO (Utrecht), 104 pp.

Van Balen, R.T., Verweij, J.M., Van Wees, J.D., Simmelink, H., Van Bergen, F. \& Pagnier, H.J.M., 2002. Deep subsurface temperatures in the Roer Valley Graben and the Peelblock, the Netherlands - new results. Netherlands Journal of Geosciences 81: 19-26.

Van Dalfsen, W., 1983. Het ondiep ondergrondse temperatuurveld in Nederland. Dienst Grondwater Verkenning TNO (Delft), Report number Report 0S 83-31.

Van Doorn, T.H.M. \& Rijkers, R.H.B., 2002. The Netherlands. In: Hurter, S. \& Haenel, R. (eds): Atlas of Geothermal Resources in the European Community. Office for Official Publications of the European Communities (Luxemburg).

Van Engen, H., 1975. An interpretation of Groningen subsurface temperature data. Geologie en Mijnbouw 54: 177-183.

Van Wees, J.D., Stephenson, R.A., Ziegler, P.A., Bayer, U., McCann, T., Dadlez, R., Gaupp, R., Narkiewicz, M., Bitzer, F. \& Scheck, M., 2000. On the origin of the Southern Permian Basin, Central Europe. Marine and Petroleum Geology 17: 43-59.

Van Wees, J.D., Van Bergen, F., David, P., Nepveu, M., Beekman, F., Cloetingh, S.A.P.L. \& Bonté, D., 2009. Probabilistic tectonic heat flow modeling for basin maturation: Assessment method and applications. Marine and Petroleum Geology 26: 536-551.
Vermooten, J.S.A., Verweij, J.M. \& Simmelink, H.J., 2004. Quality control, correction and analysis of temperature borehole data in offshore Netherlands. Report A: Quality control and correction of temperature borehole data; Part B: Analysis and interpretation of corrected temperatures from wells in offshore Netherlands 'Influence of Zechstein salt diapirs and pillows on the geothermal gradient'. Netherlands Institute of Applied Geoscience TNO - National Geological Survey (Utrecht). Report number NITG 04-043-B0506, 75 pp.

Verweij, J.M., 2003. Fluid flow systems analysis on geological timescales in onshore and offshore Netherlands, with special reference to the Broad Fourteens Basin. PhD thesis, Vrije Universiteit (Amsterdam), 278 pp.

Verweij, J.M., Souto Carneiro Echternach, M., Witmans, N. \& Abdul Fattah, R., 2012. Reconstruction of basal heat flow, surface temperature, source rock maturity and hydrocarbon generation in salt-dominated Dutch Basins. In: Peters, K., Curry, D. \& Kacewicz, M. (eds): Basin Modeling: New horizons in research and applications. AAPG Hedberg Series: 1-22.

Verwer, J.G., 1977. Explicit Runge-Kutta methods for parabolic partial differential equations. Applied Numerical Mathematics 22: 359-379.

Visser, W.A., 1978. Early subsurface temperature measurements in the Netherlands. Geologie en Mijnbouw 57: 1-10.

Ziegler, P.A., 1990. Geological Atlas of Western and Central Europe ( $2^{\text {nd }}$ edition). Shell Internationale Petroleum Maatschappij B.V.; Geological Society Publishing House (Bath), 239 pp. 